\title{
Leptin signaling and leptin resistance
}

\author{
Yingjiang Zhou ${ }^{1}$ and Liangyou Rui ${ }^{2, 凶}$ \\ ${ }^{1}$ Cambridge Laboratories, Pfizer Worldwide Research \& Development, Massachusetts 02139, \\ USA \\ 2Department of Molecular and Integrative Physiology, University of Michigan Medical School, Ann \\ Arbor, Michigan 48109, USA
}

\begin{abstract}
Leptin is secreted into the bloodstream by adipocytes and is required for the maintenance of energy homeostasis and body weight. Leptin deficiency or genetic defects in the components of the leptin signaling pathways causes obesity. Leptin controls energy balance and body weight primarily by targeting LEPRb-expressing neurons in the brain, particularly in the hypothalamus. These LEPRb-expressing neurons function as the first-order neurons that project to the secondorder neurons located within and outside the hypothalamus, forming a neural network that controls the energy homeostasis and body weight. Multiple factors, including inflammation and ER stress, contribute to leptin resistance, and leptin resistance is the key risk factor for obesity. This review is focused on recent advance about leptin action, leptin signaling, and leptin resistance.
\end{abstract}

\section{Keywords}

leptin signaling; leptin receptor; energy balance; leptin resistance; obesity

\section{Introduction}

Obesity is closely associated with various metabolic disorders including dyslipidemia, cardiovascular disease, stroke, insulin resistance, and Type 2 diabetes [1]. With the rapid upsurge of global obesity epidemic, obesity is becoming a challenging public health problem. In 2008, more than 1.4 billion adults worldwide were overweight (Body Mass Index, BMI 225), and approximately 500 million adults worldwide were obese (BMI 230 ) [2]. Medical costs associated with obesity become a heavy social burden.

Body weight is controlled by energy intake and energy expenditure [3]. The energy imbalance results in excessive calorie accumulation in the form of triglycerides in adipose tissues, leading to overweight and obesity. In the normal conditions, adipose tissues closely commute with the brain to maintain energy homeostasis and body weight. Adipose tissues secret a variety of humoral factors, collectively called adipokines, to regulate nutrient metabolism. Some adipokines (e.g. leptin) serve as adiposity signals to convey the

\footnotetext{
${ }^{\bowtie}$ Correspondence to: Liangyou Rui, Department of Molecular \& Integrative Physiology, University of Michigan Medical School, Ann Arbor, MI 48109-0622, Tel. (734) 615-7544; FAX. (734) 647-9523; ruily@umich.edu.
} 
information about the body energy storage and availability to the brain. The brain, particularly the hypothalamus, senses and integrates these adiposity signals and maintains energy homeostasis and body weight by controlling feeding behavior and energy expenditure.

Leptin is the key adipokine that mediates the adipose tissue-brain communication in the maintenance of energy homeostasis and normal body weight [3]. Leptin is encoded by the $o b$ gene that was first cloned by Friedman and colleagues in 1994 [4]. Afterwards, numerous studies established the crucial role of leptin in controlling energy balance and body weight in both rodents and humans. In mice, genetic leptin deficiency (ob/ob mice) or lack of functional leptin receptor ( $d b / d b$ mice) results in morbid obesity and type 2 diabetes $[4,5]$. Albeit rare, congenital leptin deficiency causes severe hyperphagia and early-onset obesity in humans [6-8]. As expected, a leptin replacement therapy reverses obesity and significantly improves obesity-associated metabolic disorders in leptin-deficiency patients [8-11]. However, in most cases, circulating leptin levels are abnormally higher in obesity patients than in normal subjects. These patients are believed to develop leptin resistance, defined by the reduced ability of leptin to suppress appetite and weight gains. How does leptin resistance develop? What are the molecular mechanisms underlying leptin resistance?

Can leptin resistance be corrected? In this review, we focus on leptin signaling pathways and highlight the current understanding of leptin resistance.

\section{Leptin and the leptin receptors}

Leptin is a $16-\mathrm{kDa}$ polypeptide that is primarily produced in white adipose tissues and secreted into the circulation [12]. Leptin expression is regulated by a variety of hormones, including insulin, glucocorticoids, and leptin itself [13]. FOS-like antigen 2 (FOSL2) is a key transcription factor that controls leptin expression in adipocytes [14]. Circulating leptin levels are in proportion to body fat mass, thus serving as an adiposity signal of the total body energy stores $[15,16]$. Circulating leptin levels also fluctuate in accord to changes in nutritional states [17]. Plasma leptin levels are decreased by fasting before fat depletion[17]. Leptin is also expressed at low levels in other tissues, including bone marrow, ovary, placenta, stomach, and lymphoid tissue $[13,18]$; however, the physiological function of this locally produced leptin remains largely unknown.

The central nervous system (CNS), particularly the hypothalamus, is believed to be the main leptin target and mediates leptin's anti-obesity action [19, 20]. Leptin exerts its biological action through binding to and activating the long form of leptin receptors (LEPRb) that is extensively expressed in many brain regions [21-24]. In addition to the brain, LEPRb is also expressed in peripheral tissues, but the physiological function of peripheral LEPRb remains to be determined [5, 25]. A single Lepr gene produces six LEPR isoforms (LEPRa, b, c, d, e, and f) via alternative mRNA splicing, and all isoforms have the identical N-terminal extracellular domain that binds to leptin $[25,26]$. These isoforms differ in their C-terminal intracellular domains and are divided into three categories: short (LEPRa, c, d, and f), long (LEPRb), and secreted (LEPRe) forms [27]. LEPRb is the only form that has a full-length intracellar domain of approximate 300 amino acid residues and mediates leptin signaling [28-30]. As expected, LEPRb-deficient $d b / d b$ mice display the obesity phenotypes similar to 
that in leptin-deficient $o b / o b$ mice and in $d b^{3 J} / d b^{3 J}$ mice that are deficient of all forms of leptin receptors [20,27]. The function of short-form LEPRs is less understood and may be involved in leptin transportation and clearance $[27,31,32]$.

\section{Leptin receptor signaling}

LEPRb is a member of interleukin 6 (IL-6)-type cytokine receptor family and has an extracellular domain, a single membrane-spanning domain, and an intracellular domain[28, 29, 33]. LEPRb does not contain intrinsic enzymatic activity but bind to a cytoplasmic tyrosine kinase called Janus kinase 2 (JAK2) [28, 33]. Leptin stimulates JAK2 activation that subsequently autophosphorylates on multiple tyrosines [26, 34]. JAK2 also phosphorylates LEPRb on three tyrosine residues: $\mathrm{Tyr}^{985}$, $\mathrm{Tyr}^{1077}$, and $\mathrm{Tyr}^{1138}$ (Fig. 1) [3436]. Phopho-Tyr ${ }^{985},-\mathrm{Tyr}^{1077}$, and -Tyr ${ }^{1138}$ serve as binding sites for additional signaling molecules that contain the Src homology 2 (SH2) domain, and recruit these downstream molecules to the LEPRb-JAK2 complex to allow JAK2 to phosphorylate these effector proteins [37]. Aside from JAK2, the Src tyrosine kinase family members appear also to be involved in mediating leptin signaling independently of JAK2 [38].

\section{LEPRb Tyr ${ }^{1138}$-emanated JAK2/STAT3 signaling}

In response to leptin, JAK2 phosphorylates LEPRb on $\mathrm{Tyr}^{1138}$, and phospho-Tyr ${ }^{1138}$ recruits the SH2 domain of signal transducer and activator of transcript 3 (STAT3) [37]. STAT3 is subsequently phosphorylated by LEPRb-associated JAK2, resulting in dimerization and nuclear translocation [39]. In nuclei, STAT3 dimers act as a transcription factor to regulate the expression of STAT3 target genes, including suppressor of cytokine signaling 3 (SOCS3) [34, 40]. A large body of genetic evidence demonstrates that the JAK2/ STAT3 pathway is required for the anti-obesity effect of leptin. Disruption of the STAT3 binding site by a replacement of Tyr ${ }^{1138}$ with Ser or Phe results in hyperphagia and obesity to a similar degree as that in $d b / d b$ mice $[41,42]$. Either neuron-specific or LEPRexpressing neuron-specific deletion of STAT3 leads to profound obesity in mice [43, 44].

\section{LEPRb Tyr ${ }^{1077}$-emanated JAK2/STAT5 signaling}

Leptin activates STAT5 via phospho-Tyr ${ }^{1077}$, which binds to the SH2 domain of STAT5 and allows JAK2 to tyrosyl phosphorylate and activate STAT5 [45, 46]. Tyr ${ }^{1138}$ also partially contributes to STAT5 activation [45]. Elimination of STAT5 in the CNS results in hyperphagia and obesity, whereas activation of STAT5 in hypothalamic neurons suppresses food intake in mice [47]. The results suggest the JAK2/STAT5 pathway also contribute to the anti-obesity action of leptin.

\section{LEPRb Tyr ${ }^{985}$-emanated SHP2/ERK signaling}

Phosphorylation of $\mathrm{Tyr}^{985}$ provides a binding site for the $\mathrm{SH} 2$ domain of protein tyrosine phosphatase 2 (SHP2) [48, 49]. SHP2 mediates leptin-stimulated activation of the extracellular signal-regulated kinase (ERK) pathway [48, 49]. SHP2 may also down-regulate JAK2/STAT3 signaling under some conditions [50]. Deletion of the $S H P 2$ gene in the brain results in early-onset obesity in mice, suggesting that the SHP2 pathway is also important in mediating leptin's anti-obesity action [51-54]. In agreement with this idea, pharmacological 
inhibition of the ERK pathway attenuates the ability of leptin to suppress food intake and stimulate brown adipose tissue (BAT) thermogenesis in mice, indicating the involvement of SHP2/ERK pathway in both anti-obesity and thermogenic effects of leptin [49].

Phospho-Tyr ${ }^{985}$ also binds to the SH2 domain of SOCS3, and SOCS3 in turn suppresses the activation of the LEPRb/JAK2 pathways [55]. It is likely that during the initial phase of leptin stimulation, phospho-Tyr ${ }^{985}$ may predominantly activate the SHP2/ERK pathway that mediates leptin's anti-obesity action. In agreement with this idea, one study reported that elimination of $\mathrm{Tyr}^{985}$ phosphorylation by a replacement of $\mathrm{Tyr}^{985}$ with Phe promotes dietinduced leptin resistance and obesity [56]. Leptin stimulates the expression of SOCS3 that competes with SHP2 for the phospho-Tyr ${ }^{985}$ and progressively attenuates the SHP2-ERK pathway. Under these conditions, $\mathrm{Tyr}^{985}$ phosphorylation provides a SOCS3-meidated negative feedback mechanism to downregulate leptin action. Consistent with this hypothesis, another study reported that elimination of $\mathrm{Tyr}^{985}$ phosphorylation protects against diet-induced obesity in female mice [57]. The reasons for this discrepancy between these two studies remain unclear. It is likely that the levels of intracellular SOCS3 may determine the outcome of phospho-Tyr ${ }^{985}$ as either a stimulatory or an inhibitory site for leptin action (Fig. 1).

LEPRb appears to be able to regulate nutrient metabolism by an additional mechanism independently of phosphorylation of $\mathrm{Tyr}^{985}, \mathrm{Tyr}^{1077}$, and $\mathrm{Tyr}^{1138}$. Mice with a replacement of all the three Tyr with Phe residues display the obesity phenotypes to a same degree as $d b / d b$ mice; however, $d b / d b$ mice have more severe abnormal glucose metabolism [26, 42].

\section{IRS/PI3K signaling}

The insulin receptor substrate (IRS)/phosphoinositide 3-kinase (PI3K) pathway is also required for leptin action $[42,58]$. Leptin activates the IRS/PI3K pathway both in cultured cells and in the hypothalamus [26, 59-61]. Deletion of IRS2 in the brain causes obesity in mice [62, 63]. Pharmacological inhibition of PI3K in the hypothalamus prevents leptininduced anorexia in mice [58]. These observations demonstrate the importance of IRS/PI3K cascade in proper leptin receptor signaling and its anti-obesity effects. Mechanistically, we showed that SH2B1, a SH2 domain-containing adaptor protein, binds to both JAK2 and the IRS proteins and mediates the activation of the PI3K pathway (Fig. 1) [64]. Disruption of the $S H 2 B 1$ gene results in leptin resistance and obesity $[65,66]$. Two downstream events of the PI3K cascades are described below [67].

The Fox01 signaling branch-One important downstream effector of the PI3K/Akt pathway is forkhead box O1 (FoxO1), a key transcription factor for gluconeogenesis [68]. Akt phosphorylates FoxO1 on multiple sites, resulting in cytoplasmic retention and inactivation of FoxO1 [67]. Overexpression of a constitutively active FoxO1 mutant in the ARC abolishes leptin responses and increases food intake and body weight, whereas overexpression of a transcription-deficient FoxO1 mutant or FoxO1 knockdown in the ARC has an opposite effect $[68,69]$. Deletion of FoxO1 in POMC neurons results in decreased food intake and body weight in mice [70]. Deletion of IRS2 in LEPRb neurons leads to energy imbalance and obesity, and deletion FoxO1 reverses the obesity phenotypes in IRS2 
null mice [71]. Mechanistically, FoxO1 regulates the expression of important neuropeptides including POMC, NPY, and AgRP, and it also antagonizes the transcriptional activity STAT3 $[69,72]$.

The mTORC1/S6K signaling branch-The mammalian target of rapamycin (mTOR)/ ribosomal S6 kinase (S6K) pathway is another downstream event of the IRS/PI3K pathway [26]. Leptin stimulates the activation of the mTOR complex 1 (mTORC1), which in turn phosphorylates and activates S6K in the hypothalamus [73, 74]. Intracerebroventricular administration of L-leucine activates hypothalamic mTORC1 and decreases food intake and body weight in rats, whereas rapamycin, an mTORC1 inhibitor, exerts an opposite action [73]. Constitutive activation of S6K in the mediobasal hypothalamus (MBH) protects against HFD-induced obesity in rats, whereas inhibition of S6K activity in the MBH results in increased food intake and body weight [75]. These findings establish the critical role of the mTORC1/S6R pathway in mediating leptin regulation of energy homeostasis in mammals $[73,75]$.

\section{Other signaling pathways}

The calcium calmodulin-dependent protein kinase kinase (CaMKK2)/5'-AMP-activated protein kinase (AMPK)/acetyle-CoA carboxylase (ACC) pathway has also been suggested to be involved in the leptin receptor signaling $[26,76,77]$. AMPK is activated by lower ATP/ADP ratios and serves as an intracellular sensor for energy levels [76]. Recently, we showed that glucose enhances leptin signaling through modulation of AMPK activity [78]. However, several key signaling steps of the CaMKK2/AMPK/ACC pathway in the leptin receptor signaling are yet to be defined.

\section{Leptin target neural circuitry in the hypothalamus}

LEPRb is widely expressed in many brain regions at different levels [21], among which the hypothalamus express high levels of LEPRb [21-24, 26, 79-81]. Mice with deletion of hypothalamic LEPRb develop early-onset obesity [82]. Additionally, LEPRb is also expressed in some non-neuronal cells in the CNS and may be involved in regulation of energy balance as well as other functions of leptin [83].

\section{Leptin target neurons in the hypothalamus}

Leptin target neurons are distributed in all regions of the hypothalamus, including the arcuate nucleus (ARC), ventral premammillary nucleus (PMV), medial preoptic nucleus (MEPO), dorsomedial (DMH), ventromedial (VMH), paraventricular hypothalamic nucleus (PVH), and lateral hypothalamic area (LHA) [21-24, 26, 79-81]. LEPRb-expressing neurons in the ARC have been extensively investigated[21]. Restoration of LEPRb expression in the ARC attenuates the obesity phenotypes of LEPR-deficient rats, establishing a key role of ARC leptin action [84]. At least two subpopulations of ARC LEPRb-expressing neurons, pro-opriomelanocortin (POMC) neurons and agouti-related protein $(\mathrm{AgRP})$ neurons, have been identified in the ARC [26, 85].

POMC neurons express anorexigenic (appetite-suppressing) neuropeptides including POMC and cocaine- and amphetamine-regulated transcript (CART) [86, 87]. Leptin acts via LEPRb 
to stimulate the synthesis of POMC that generates a-melanocyte-stimulating hormone ( $\mathrm{a}$ MSH) [88-90]. a-MSH reduces body weight by binding to and activating melanocortin-3 receptor (MC3R) and melanocortin-4 receptor (MC4R) [3, 91, 92]. MC4R knockout mice develop leptin resistance and obesity, and MC3R null mice also exhibit the obesity phenotypes, but to a lesser degree [92-94]. Importantly, many genetic variants of the POMC and $M C 4 R$ genes have been identified to be associated with human obesity [95-97]. These observations indicate that the central melanocortin system is required for leptin to promote weight loss.

In contrast to POMC neurons, the ARC AgRP neurons express orexigenic (appetitestimulating) neuropeptide Y (NPY) and AgRP [98]. NPY and AgRP may have complementary rather than identical functions [99]. Adult-onset ablation of AgRP neurons inhibits food intake in mice [100-102], whereas activation of AgRP neurons is sufficient to stimulate food intake in dependently of the melanocortin system [103]. Leptin inhibits both AgRP neuronal activity and expression of NPY and AgRP [26, 27, 88]. AgRP exerts its anorexigenic action by acting both as an a-MSH antagonist and a MC4R inverse agonist [27, 104]. Genetic deletion of the $N P Y$ and/or $A g R P$ genes has a mild effect on body weight in mice, suggesting the existence of other modulators in the AgRP neurons [105]. For example, synaptic release of gamma-aminobutyric acid (GABA) from AgRP neurons is suggested to provide an inhibitory mechanism for ARC POMC neurons [106]. Surprisingly, deletion of LEPRs in either POMC or AgRP neurons results in a very milder obesity phenotype compared with that in $d b / d b$ mice $[87,107]$. Restoration of leptin signaling in the ARC of LEPR-null animals modestly alleviates the hyperphagia and obesity phenotypes $[108,109]$. These observations suggest that other LEPRb-expressing neurons also mediate leptin's action in addition to ARC POMC and AgRP neurons [110]. Indeed, LEPRs are expressed in many other brain areas beyond the ARC, and these extra-ARC sites account for $80-85 \%$ of the total number of LEPR-expressing neurons in the brain [27]. Several recent studies report that LEPRb in the nitric oxide synthase-1 (NOS1)-expressing neurons and GABAergic neurons play an important role in mediating the anti-obesity effects of leptin $[110,111]$.

\section{Leptin target neural circuits}

LEPRb-expressing neurons are clustered in the specific regions and serve as first-order neurons to sense adiposity signals carried by leptin and other hormones and/or nutrients. These first-order neurons project to the second-order neurons located in many hypothalamic areas (VMH, LAH, and PVN) as well as in extrahypothalamic sites (e.g. VTA, and the brain stem), forming a sophisticated neural network that mediates the homeostatic regulation of energy homeostasis and body weight [26, 27]. For instance, the PVH receives intense neuronal projections from the ARC, VMH and $\mathrm{DMH}$ and serves as a common output to regulate energy expenditure and satiety [85]. ARC POMC neuron-derived a-MSH binds to and activates the MC4R in PVH neurons, stimulating the expression and secretion of thyrotropin-releasing hormone (TRH) $[26,112,113]$. In contrast, AgRP and NPY inhibit TRH secretion $[112,113]$. TRH activates the pituitary-thyroid pathway, thus promoting energy expenditure. PVH-specific restoration of MC4R rescues the hyperphagia and obesity phenotypes of MC4R-null mice [114]. Interestingly, a subset of the PVN neurons also 
express LEPRb and leptin activates the LEPRb pathways in these neurons, suggesting that leptin is able to regulate a subset of the PVN neurons both directly and indirectly via the ARC first-order neurons [115]. ARC neurons also innervate VMH/DMH neurons, and leptin stimulates the expression of anorexigenic brain-derived neurotrophic factor (BDNF) presumably via the POMC projections to the VMH [116, 117]. Moreover, the hypothalamic neural connections are bidirectional, and VMH-derived BDNF may modulate ARC neuronal activity [117]. Additionally, the hypothalamic melanocortin system also has cross-talk with the brainstem-derived serotonin (BDS) system, which may also be involved in leptin regulation of bone mass and energy balance [118].

\section{Molecular mechanisms of leptin resistance}

Leptin resistance is considered as the primary risk factor for the pathogenesis of overweight and obesity [119]. Many mechanisms have been proposed to explain leptin resistance, including impairment in leptin transportation, leptin signaling, and leptin target neural circuits $[119,120]$.

\section{Impairment in leptin transportation}

The majority of LEPRb-expression neurons in the brain are separated from circulating leptin by the blood-brain barrier (BBB). Leptin is actively transported across the BBB in a saturable manner [121]. Two short forms of LEPRa and LEPRe are believed to mediate leptin transport across the BBB [122-124]. Brain leptin transport is impaired in both humans and mice with obesity, thus contributing to leptin resistance [125-127]. In HFD-fed mice, leptin transport across the BBB is substantially decreased [127]. In obese subjects with severe hyperleptinemia, leptin levels in the cerebrospinal fluid only marginally increase [126]. However, the relative contributions of impaired brain leptin transport to systemic leptin resistance remain to be determined. Firstly, the neuronal projections of the ARC LEPRb-neurons are detected in the median eminence that lacks the BBB, and these neurons may directly expose to circulating leptin $[120,128]$. Secondly, HFD feeding attenuates the anorexigenic effect of intracerebroventricular administration of leptin [125]. Thirdly, impairment in the brain leptin transport may be secondary to systemic leptin resistance during the pathogenesis of obesity [120, 129].

\section{Impairment in LEPRb signaling}

Defects in each component of the LEPRb signaling cascades are expected to result in leptin resistance. We describe three potential mechanisms: reduction in the cell surface LEPRb levels, upregulation of negative regulators, and downregulation of positive regulators [26, 120].

The majority of LEPRb are localized in the Golgi apparatus and endosomes, and the function of these intracellular LEPRb is unclear; a small portion of LEPRb is present at the plasma membrane $[130,131]$. The LEPRb trafficking to the cell surface is mediated by multiple factors including Bardet-Biedl syndrome (BBS) proteins [132]. BBS deficiency impairs LEPRb trafficking and leptin signaling, resulting in obesity in both humans and mice $[132,133]$. Additionally, the plasma membrane LEPRb is constitutively internalized 
via endocytosis in a ligand-independent manner [130]. A reduction in the plasma membrane LEPRb expression, caused by a decrease in trafficking and/or increase in endocytosis, is expected to contribute to leptin resistance.

Leptin signaling is negatively regulated by many intracellular proteins, including SOCS3, protein tyrosine phosphatase 1B (PTP1B), and T cell protein tyrosine phosphatase (TCPTP) (Fig. 1) [134-136]. SOCS3 is a leptin target gene and provides a negative feedback regulatory mechanism to prevent over-activation of the LEPRb pathways [134]. In agreement with this idea, mice with LEPRb overexpression in the POMC neurons are more susceptible to HFD-induced obesity [137]. SOCS3 inhibits JAK2 kinase activity by directly binding to JAK2 [138]. As discussed previously, SOCS3 also binds to phospho-Tyr ${ }^{985}$ and inhibits LEPRb signaling, probably by competing with SHP2 for the same binding site [55, 57]. Systemic haploinsufficiency of SOCS3 improves leptin sensitivity and attenuates HFDinduced obesity in mice [139]. Neuron-specific deletion of SOCS3 also protects against dietinduced leptin resistance and obesity [140, 141]. In contrast, transgenic overexpression of SOCS3 in POMC neurons leads to leptin resistance and obesity [142]. The levels of hypothalamic SOCS3 are higher in HFD-fed or aged mice, which may contribute to leptin resistance [134]. PTP1B, a class 1 non-receptor protein tyrosine phosphatase, dephosphorylates and inhibits JAK2 [135, 143]. PTP1B-null mice are protected from dietinduced leptin resistance and obesity $[143,144]$. Neuronal deletion of the PTPIB gene results in decreased food intake and increased energy expenditure [145, 146]. Ablation of PTP1B in POMC neurons also leads to elevated energy expenditure [147]. TCPTP, another non-receptor PTP, dephosphorylates STAT1 and STAT3 [53]. Inhibition of neuronal PCPTP also improves leptin sensitivity in obese mice, and deletion of both PTP1B and TCPTP in the brain has an additive effect [136]. Furthermore, the expression of hypothalamic PTP1B and TCPTP is higher in mice with diet- induced obesity, providing additional evidence that PTP1B and TCPTP contribute to leptin resistance and the progression to obesity $[136,148$, 149]. Additionally, phosphatase and tensin homolog (PTEN) and tyrosine phosphatase epsilon (RPTPe) are also suggested to be involved in the development of leptin resistance [150-153].

We have recently identified $\mathrm{SH} 2 \mathrm{~B} 1$ as a novel endogenous positive regulator of leptin signaling [64-66, 119, 154]. SH2B1 is an SH2 and pleckstrin homology (PH) domaincontaining adaptor protein and was initially identified as a JAK2-binding protein [155]. Deletion of the $S H 2 B 1$ gene results in leptin resistance, hyperphagia, and morbid obesity [65], and neuron-specific restoration of SH2B1 reverses the obesity phenotypes of SH2B1deficient mice [66]. In agreement, ectopic expression of a dominant negative SH2B1 mutant in the brain causes obesity in wild-type mice [119], whereas transgenic over-expression of $\mathrm{SH} 2 \mathrm{~B} 1 \beta$ in the brain protects mice from HFD-induced obesity [66]. SH2B1 appears to enhance LEPRb signaling by several mechanisms. Leptin stimulates JAK2 phosphorylation on $\mathrm{Tyr}^{813}$ that in turn binds to the SH2 domain of SH2B1; SH2B1-JAK2 interactions increase JAK2 kinase activity, thus enhancing the activation of the pathways downstream of JAK2 $[65,154]$. Leptin also stimulates the binding of SH2B1 to IRS proteins, thus allowing SH2B1-associated JAK2 to phosphorylate IRS proteins [64]. SH2B1-IRS interactions also inhibit tyrosine dephosphorylation of IRS proteins, thus prolonging the activation of the 
IRS-PI3K pathway [156]. The metabolic function of SH2B1 is evolutionarily conserved in fruit flies, mice, and humans [96, 157-162]. Genome-wide association studies (GWAS) show that single nucleotide polymorphisms (SNPs) of the $\mathrm{SH} 2 \mathrm{~B} 1$ loci are linked to obesity in different ethnic populations [96, 158-162]. Chromosomal deletions of an SH2B1containing fragment are associated with severe early-onset obesity [163].

\section{Impairment in leptin target neural circuits}

The melanocortin system governs the hypothalamic neural circuitry that controls energy homeostasis. Deficiency of MC4R results in morbid obesity in both mice and humans [164167]. Leptin stimulates the expression of BDNF in the VMH via a MC4R-dependent mechanism [116]. Inhibition of the BDNF/TrkB pathways results in leptin resistance, hyperphagia, and obesity in both mice and humans, whereas activation of the BDNF/TrkB signaling induces weight loss in rats[116, 168-170].

\section{Potential contributors to leptin resistance in obesity}

Many factors have been reported to cause leptin resistance in obesity. Here we discuss four factors: hyperleptinemia, inflammation, and endoplasmic reticulum (ER) stress, and defective autophagy.

\section{Hyperleptinemia}

Hyperleptinemia per se is a contributing factor to development of leptin resistance. Chronic exposure to high levels of circulating leptin (hyperleptinemia) causes leptin resistance, presumably by over-activating negative feedback regulators [171]. In agreement with this idea, expression of a constitutively active form of STAT3 in POMC neurons results in leptin resistance, hyperphagia, and obesity [172]. Lowering plasma leptin levels through clamping does not prevent diet-induced fed obesity but significantly improves leptin sensitivity [172]. Both inhibiting adipocyte leptin production and increasing kidney leptin clearance are able to restore leptin sensitivity in mice [173].

\section{Inflammation}

Low-grade, chronic inflammation is closely associated with various metabolic disorders including obesity [174]. HFD-feeding promotes inflammation not only in the peripheral tissues but also in the hypothalamus [175, 176]. Saturated fatty acids, which are elevated in obesity, are able to bind to and activate toll-like receptor 4 (TLR4) [177].

Intracerebroventricular administration of TLR4 neutralizing antibody diminishes the ability of saturated fatty acids to induce hypothalamic inflammation and suppress food intake and weight gain in rats [178]. Deletion of neuronal TLR adaptor molecule MyD88 protects from HFD-induced leptin resistance and obesity [179]. Both systemic and neuron-specific deletion of c-Jun amino-terminal kinase 1 (JNK1), a key regulator of inflammation, protects mice from HFD-induced obesity [180, 181]. Activation of the hypothalamic IKK $\beta / \mathrm{NF}-\kappa \mathrm{B}$ pathway induces leptin resistance, whereas inhibition of hypothalamic IKK $\beta$ protects against obesity in mice [176]. 


\section{ER stress}

The ER is a cellular organelle where most secreted and transmembrane proteins are synthesized, folded, and sorted [182]. The ER processing capacity is affected by both the state of the cell and environmental conditions [182]. Protein overloading results in accumulation of unfolded or misfolded proteins in the ER lumens, causing ER stress. ER stress activates the unfolded protein response (UPR) pathways, including the inositolrequiring protein-1 (IRE1), activating transcription factor-6 (ATF6), and protein kinase RNA (PKR)-like ER kinase (PERK) pathways [182]. The UPR relieves ER stress by decreasing protein synthesis and influx into the ER, increasing protein-folding capacity of the ER via up-regulating the expression of ER chaperons, and clearing unfolded or misfolded proteins from the ER through proteasome-mediated degradation [182]. Cell death is triggered if the UPR fails to relieve ER stress [182]. ER stress is associated with a variety of metabolic diseases including obesity, insulin resistance, and diabetes[183]. Recently, several groups have reported the role of ER stress in the development of leptin resistance and obesity [176, 184, 185]. Hypothalamic ER stress is observed in HFD-fed mice [184]. Deletion of neuronal X-box binding protein 1 (XBP-1), an important regulator of ER homeostasis, results in hypothalamic ER stress and leptin resistance [184]. Central administration of pharmacological ER stress inducers impairs leptin signaling, whereas treatments with chemical ER chaperons relieve hypothalamic ER stress and decrease body weights in $o b / o b$ mice [184-186]. Physical exercises improve hypothalamic leptin sensitivity at least in part through suppressing hypothalamic IKK $\beta$ and ER stress in rodents[187].

\section{Defective autophagy}

Autophagy has been reported to be involved in the regulation of energy homeostasis [188191]. Leptin treatments induce autophagy both in cultured cells and in animals [188]. Inhibition of autophagy in the mediobasal hypothalamus by knocking down autophagyrelated protein 7 (Atg7) leads to energy imbalance and obesity in mice [189]. POMC-neuron specific Atg7-knockout mice display leptin resistance [191]; in contrast, AgRP neuronspecific Atg7-knockout mice exhibit reduced body weight and adiposity without altering food intake [190]. Clearly, more studies are warranted to clarify the cell type-specific actions of autophagy under normal and obesity conditions.

\section{Conclusions and future directions}

Leptin has been firmly established as the essential hormone for the maintenance of energy homeostasis and body weight, and leptin resistance has been widely recognized as the key risk factor for obesity. Leptin promotes weight loss primarily by activating the LEPRb pathways in the brain, particularly in the hypothalamus. These pathways act coordinately to mediate leptin's anti-obesity action. LEPRb-expressing neurons are located in many brain areas, and these neurons form a sophisticated network to control energy balance and body weight. Multiple factors, including inflammation and ER stress, have been identified as causal factors for leptin resistance. Genetic studies, including mouse genetic analysis and GWAS, have provided important information about potential obesity genes. However, the anatomic connection and synaptic transmission of the brain neural circuitry that control 
energy homeostasis and body weight remain largely unknown. The interactions between the neural circuits that mediate homeostatic and hedonic regulation of food intake are unclear. It is also unclear how the different branches of the LEPRb pathways act specifically and/or coordinately to regulate different aspects of feeding behavior and energy expenditure. A large portion of molecular events that lead to leptin resistance remains to be identified. Additionally, we just begin to appreciate the contribution of hypothalamus plasticity and neurogenesis to the maintenance of energy homeostasis and body weight. We expect to have exciting new findings in these areas in the future.

\section{Acknowledgments}

This work was supported by grants RO1 DK065122 and DK091591 from the NIDDK (to L.R.).

\section{Reference}

1. Kopelman PG. Obesity as a medical problem. Nature. 2000; 404(6778):635-643. [PubMed: 10766250]

2. Finucane MM, Stevens GA, Cowan MJ, Danaei G, Lin JK, Paciorek CJ, Singh GM, Gutierrez HR, Lu Y, Bahalim AN, Farzadfar F, Riley LM, Ezzati M. National, regional, and global trends in bodymass index since 1980: systematic analysis of health examination surveys and epidemiological studies with 960 country-years and 9.1 million participants. Lancet. 2011; 377(9765):557-567. [PubMed: 21295846]

3. Schwartz MW, Woods SC, Porte D Jr, Seeley RJ, Baskin DG. Central nervous system control of food intake. Nature. 2000; 404(6778):661-671. [PubMed: 10766253]

4. Zhang Y, Proenca R, Maffei M, Barone M, Leopold L, Friedman JM. Positional cloning of the mouse obese gene and its human homologue. Nature. 1994; 372(6505):425-432. [PubMed: 7984236]

5. Tartaglia LA, Dembski M, Weng X, Deng N, Culpepper J, Devos R, Richards GJ, Campfield LA, Clark FT, Deeds J, Muir C, Sanker S, Moriarty A, Moore KJ, Smutko JS, Mays GG, Wool EA, Monroe CA, Tepper RI. Identification and expression cloning of a leptin receptor, OB-R. Cell. 1995; 83(7):1263-1271. [PubMed: 8548812]

6. Montague CT, Farooqi IS, Whitehead JP, Soos MA, Rau H, Wareham NJ, Sewter CP, Digby JE, Mohammed SN, Hurst JA, Cheetham CH, Earley AR, Barnett AH, Prins JB, O'Rahilly S. Congenital leptin deficiency is associated with severe early-onset obesity in humans. Nature. 1997; 387(6636):903-908. [PubMed: 9202122]

7. Strobel A, Issad T, Camoin L, Ozata M, Strosberg AD. A leptin missense mutation associated with hypogonadism and morbid obesity. Nat Genet. 1998; 18(3):213-215. [PubMed: 9500540]

8. Farooqi IS, Jebb SA, Langmack G, Lawrence E, Cheetham CH, Prentice AM, Hughes IA, McCamish MA, O'Rahilly S. Effects of recombinant leptin therapy in a child with congenital leptin deficiency. N Engl J Med. 1999; 341(12):879-884. [PubMed: 10486419]

9. Gibson WT, Farooqi IS, Moreau M, DePaoli AM, Lawrence E, O'Rahilly S, Trussell RA. Congenital leptin deficiency due to homozygosity for the Delta133G mutation: report of another case and evaluation of response to four years of leptin therapy. J Clin Endocrinol Metab. 2004; 89(10):4821-4826. [PubMed: 15472169]

10. Farooqi IS, Matarese G, Lord GM, Keogh JM, Lawrence E, Agwu C, Sanna V, Jebb SA, Perna F, Fontana S, Lechler RI, DePaoli AM, O'Rahilly S. Beneficial effects of leptin on obesity, T cell hyporesponsiveness, and neuroendocrine/metabolic dysfunction of human congenital leptin deficiency. J Clin Invest. 2002; 110(8):1093-1103. [PubMed: 12393845]

11. Licinio J, Caglayan S, Ozata M, Yildiz BO, de Miranda PB, O'Kirwan F, Whitby R, Liang L, Cohen P, Bhasin S, Krauss RM, Veldhuis JD, Wagner AJ, DePaoli AM, McCann SM, Wong ML. Phenotypic effects of leptin replacement on morbid obesity, diabetes mellitus, hypogonadism, and behavior in leptin-deficient adults. Proc Natl Acad Sci U S A. 2004; 101(13):4531-4536. [PubMed: 15070752] 
12. Zhang F, Basinski MB, Beals JM, Briggs SL, Churgay LM, Clawson DK, DiMarchi RD, Furman TC, Hale JE, Hsiung HM, Schoner BE, Smith DP, Zhang XY, Wery JP, Schevitz RW. Crystal structure of the obese protein leptin-E100. Nature. 1997; 387(6629):206-209. [PubMed: 9144295]

13. Margetic S, Gazzola C, Pegg GG, Hill RA. Leptin: a review of its peripheral actions and interactions. Int J Obes Relat Metab Disord. 2002; 26(11):1407-1433. [PubMed: 12439643]

14. Wrann CD, Eguchi J, Bozec A, Xu Z, Mikkelsen T, Gimble J, Nave H, Wagner EF, Ong SE, Rosen ED. FOSL2 promotes leptin gene expression in human and mouse adipocytes. J Clin Invest. 2012; 122(3):1010-1021. [PubMed: 22326952]

15. Frederich RC, Hamann A, Anderson S, Lollmann B, Lowell BB, Flier JS. Leptin levels reflect body lipid content in mice: evidence for diet-induced resistance to leptin action. Nat Med. 1995; 1(12):1311-1314. [PubMed: 7489415]

16. Maffei M, Halaas J, Ravussin E, Pratley RE, Lee GH, Zhang Y, Fei H, Kim S, Lallone R, Ranganathan S, et al. Leptin levels in human and rodent: measurement of plasma leptin and ob RNA in obese and weight-reduced subjects. Nat Med. 1995; 1(11):1155-1161. [PubMed: 7584987]

17. Ahima RS, Prabakaran D, Mantzoros C, Qu D, Lowell B, Maratos-Flier E, Flier JS. Role of leptin in the neuroendocrine response to fasting. Nature. 1996; 382(6588):250-252. [PubMed: 8717038]

18. Mantzoros CS, Magkos F, Brinkoetter M, Sienkiewicz E, Dardeno TA, Kim SY, Hamnvik OP, Koniaris A. Leptin in human physiology and pathophysiology. Am J Physiol Endocrinol Metab. 2011; 301(4):E567-E584. [PubMed: 21791620]

19. Friedman JM, Halaas JL. Leptin and the regulation of body weight in mammals. Nature. 1998; 395(6704):763-770. [PubMed: 9796811]

20. Bates SH, Myers MG Jr. The role of leptin receptor signaling in feeding and neuroendocrine function. Trends Endocrinol Metab. 2003; 14(10):447-452. [PubMed: 14643059]

21. Gautron L, Elmquist JK. Sixteen years and counting: an update on leptin in energy balance. J Clin Invest. 2011; 121(6):2087-2093. [PubMed: 21633176]

22. Elmquist JK, Bjorbaek C, Ahima RS, Flier JS, Saper CB. Distributions of leptin receptor mRNA isoforms in the rat brain. J Comp Neurol. 1998; 395(4):535-547. [PubMed: 9619505]

23. Scott MM, Lachey JL, Sternson SM, Lee CE, Elias CF, Friedman JM, Elmquist JK. Leptin targets in the mouse brain. J Comp Neurol. 2009; 514(5):518-532. [PubMed: 19350671]

24. Schwartz MW, Seeley RJ, Campfield LA, Burn P, Baskin DG. Identification of targets of leptin action in rat hypothalamus. J Clin Invest. 1996; 98(5):1101-1106. [PubMed: 8787671]

25. Fei H, Okano HJ, Li C, Lee GH, Zhao C, Darnell R, Friedman JM. Anatomic localization of alternatively spliced leptin receptors (Ob-R) in mouse brain and other tissues. Proc Natl Acad Sci U S A. 1997; 94(13):7001-7005. [PubMed: 9192681]

26. Morris DL, Rui L. Recent advances in understanding leptin signaling and leptin resistance. Am J Physiol Endocrinol Metab. 2009; 297(6):E1247-E1259. [PubMed: 19724019]

27. Myers MG, Cowley MA, Munzberg H. Mechanisms of leptin action and leptin resistance. Annu Rev Physiol. 2008; 70:537-556. [PubMed: 17937601]

28. Baumann H, Morella KK, White DW, Dembski M, Bailon PS, Kim H, Lai CF, Tartaglia LA. The full-length leptin receptor has signaling capabilities of interleukin 6-type cytokine receptors. Proc Natl Acad Sci U S A. 1996; 93(16):8374-8378. [PubMed: 8710878]

29. Chen H, Charlat O, Tartaglia LA, Woolf EA, Weng X, Ellis SJ, Lakey ND, Culpepper J, Moore KJ, Breitbart RE, Duyk GM, Tepper RI, Morgenstern JP. Evidence that the diabetes gene encodes the leptin receptor: identification of a mutation in the leptin receptor gene in $\mathrm{db} / \mathrm{db}$ mice. Cell. 1996; 84(3):491-495. [PubMed: 8608603]

30. Chua SC Jr, Chung WK, Wu-Peng XS, Zhang Y, Liu SM, Tartaglia L, Leibel RL. Phenotypes of mouse diabetes and rat fatty due to mutations in the OB (leptin) receptor. Science. 1996; 271(5251):994-996. [PubMed: 8584938]

31. Uotani S, Bjorbaek C, Tornoe J, Flier JS. Functional properties of leptin receptor isoforms: internalization and degradation of leptin and ligand-induced receptor downregulation. Diabetes. 1999; 48(2):279-286. [PubMed: 10334302] 
32. Schaab M, Kausch H, Klammt J, Nowicki M, Anderegg U, Gebhardt R, Rose-John S, Scheller J, Thiery J, Kratzsch J. Novel regulatory mechanisms for generation of the soluble leptin receptor: implications for leptin action. PLoS One. 2012; 7(4):e34787. [PubMed: 22545089]

33. Taga T, Kishimoto T. Gp130 and the interleukin-6 family of cytokines. Annu Rev Immunol. 1997; 15:797-819. [PubMed: 9143707]

34. Banks AS, Davis SM, Bates SH, Myers MG Jr. Activation of downstream signals by the long form of the leptin receptor. J Biol Chem. 2000; 275(19):14563-14572. [PubMed: 10799542]

35. Tartaglia LA. The leptin receptor. J Biol Chem. 1997; 272(10):6093-6096. [PubMed: 9102398]

36. Hekerman P, Zeidler J, Bamberg-Lemper S, Knobelspies H, Lavens D, Tavernier J, Joost HG, Becker W. Pleiotropy of leptin receptor signalling is defined by distinct roles of the intracellular tyrosines. FEBS J. 2005; 272(1):109-119. [PubMed: 15634336]

37. White DW, Kuropatwinski KK, Devos R, Baumann H, Tartaglia LA. Leptin receptor (OB-R) signaling. Cytoplasmic domain mutational analysis and evidence for receptor homooligomerization. J Biol Chem. 1997; 272(7):4065-4071. [PubMed: 9020115]

38. Jiang L, Li Z, Rui L. Leptin stimulates both JAK2-dependent and JAK2-independent signaling pathways. J Biol Chem. 2008; 283(42):28066-28073. [PubMed: 18718905]

39. Vaisse C, Halaas JL, Horvath CM, Darnell JE Jr, Stoffel M, Friedman JM. Leptin activation of Stat3 in the hypothalamus of wild-type and ob/ob mice but not db/db mice. Nat Genet. 1996; 14(1):95-97. [PubMed: 8782827]

40. Xu AW, Ste-Marie L, Kaelin CB, Barsh GS. Inactivation of signal transducer and activator of transcription 3 in proopiomelanocortin (Pomc) neurons causes decreased pomc expression, mild obesity, and defects in compensatory refeeding. Endocrinology. 2007; 148(1):72-80. [PubMed: 17023536]

41. Bates SH, Stearns WH, Dundon TA, Schubert M, Tso AW, Wang Y, Banks AS, Lavery HJ, Haq AK, Maratos-Flier E, Neel BG, Schwartz MW, Myers MG Jr. STAT3 signalling is required for leptin regulation of energy balance but not reproduction. Nature. 2003; 421(6925):856-859. [PubMed: 12594516]

42. Jiang L, You J, Yu X, Gonzalez L, Yu Y, Wang Q, Yang G, Li W, Li C, Liu Y. Tyrosinedependent and -independent actions of leptin receptor in control of energy balance and glucose homeostasis. Proc Natl Acad Sci U S A. 2008; 105(47):18619-18624. [PubMed: 19015522]

43. Piper ML, Unger EK, Myers MG Jr, Xu AW. Specific physiological roles for signal transducer and activator of transcription 3 in leptin receptor-expressing neurons. Mol Endocrinol. 2008; 22(3): 751-759. [PubMed: 18096691]

44. Gao Q, Wolfgang MJ, Neschen S, Morino K, Horvath TL, Shulman GI, Fu XY. Disruption of neural signal transducer and activator of transcription 3 causes obesity, diabetes, infertility, and thermal dysregulation. Proc Natl Acad Sci U S A. 2004; 101(13):4661-4666. [PubMed: 15070774]

45. Gong Y, Ishida-Takahashi R, Villanueva EC, Fingar DC, Munzberg H, Myers MG Jr. The long form of the leptin receptor regulates STAT5 and ribosomal protein S6 via alternate mechanisms. J Biol Chem. 2007; 282(42):31019-31027. [PubMed: 17726024]

46. Mutze J, Roth J, Gerstberger R, Hubschle T. Nuclear translocation of the transcription factor STAT5 in the rat brain after systemic leptin administration. Neurosci Lett. 2007; 417(3):286-291. [PubMed: 17353091]

47. Lee JY, Muenzberg H, Gavrilova O, Reed JA, Berryman D, Villanueva EC, Louis GW, Leinninger GM, Bertuzzi S, Seeley RJ, Robinson GW, Myers MG, Hennighausen L. Loss of cytokine-STAT5 signaling in the CNS and pituitary gland alters energy balance and leads to obesity. PLoS One. 2008; 3(2):e1639. [PubMed: 18286195]

48. Bjorbaek C, Buchholz RM, Davis SM, Bates SH, Pierroz DD, Gu H, Neel BG, Myers MG Jr, Flier JS. Divergent roles of SHP-2 in ERK activation by leptin receptors. J Biol Chem. 2001; 276(7): 4747-4755. [PubMed: 11085989]

49. Rahmouni K, Sigmund CD, Haynes WG, Mark AL. Hypothalamic ERK mediates the anorectic and thermogenic sympathetic effects of leptin. Diabetes. 2009; 58(3):536-542. [PubMed: 19066310] 
50. Li C, Friedman JM. Leptin receptor activation of SH2 domain containing protein tyrosine phosphatase 2 modulates Ob receptor signal transduction. Proc Natl Acad Sci U S A. 1999; 96(17):9677-9682. [PubMed: 10449753]

51. He Z, Zhang SS, Meng Q, Li S, Zhu HH, Raquil MA, Alderson N, Zhang H, Wu J, Rui L, Cai D, Feng GS. Shp2 controls female body weight and energy balance by integrating leptin and estrogen signals. Mol Cell Biol. 2012; 32(10):1867-1878. [PubMed: 22431513]

52. Krajewska M, Banares S, Zhang EE, Huang X, Scadeng M, Jhala US, Feng GS, Krajewski S. Development of diabesity in mice with neuronal deletion of Shp2 tyrosine phosphatase. Am J Pathol. 2008; 172(5):1312-1324. [PubMed: 18403587]

53. St-Pierre J, Tremblay ML. Modulation of leptin resistance by protein tyrosine phosphatases. Cell Metab. 2012; 15(3):292-297. [PubMed: 22405067]

54. Zhang EE, Chapeau E, Hagihara K, Feng GS. Neuronal Shp2 tyrosine phosphatase controls energy balance and metabolism. Proc Natl Acad Sci U S A. 2004; 101(45):16064-16069. [PubMed: 15520383]

55. Bjorbak C, Lavery HJ, Bates SH, Olson RK, Davis SM, Flier JS, Myers MG Jr. SOCS3 mediates feedback inhibition of the leptin receptor via Tyr985. J Biol Chem. 2000; 275(51):40649-40657. [PubMed: 11018044]

56. You J, Yu Y, Jiang L, Li W, Yu X, Gonzalez L, Yang G, Ke Z, Li C, Liu Y. Signaling through Tyr985 of leptin receptor as an age/diet-dependent switch in the regulation of energy balance. Mol Cell Biol. 2010; 30(7):1650-1659. [PubMed: 20086094]

57. Bjornholm M, Munzberg H, Leshan RL, Villanueva EC, Bates SH, Louis GW, Jones JC, IshidaTakahashi R, Bjorbaek C, Myers MG Jr. Mice lacking inhibitory leptin receptor signals are lean with normal endocrine function. J Clin Invest. 2007; 117(5):1354-1360. [PubMed: 17415414]

58. Niswender KD, Morton GJ, Stearns WH, Rhodes CJ, Myers MG Jr, Schwartz MW. Intracellular signalling. Key enzyme in leptin-induced anorexia. Nature. 2001; 413(6858):794-795. [PubMed: 11677594]

59. Kim YB, Uotani S, Pierroz DD, Flier JS, Kahn BB. In vivo administration of leptin activates signal transduction directly in insulin-sensitive tissues: overlapping but distinct pathways from insulin. Endocrinology. 2000; 141(7):2328-2339. [PubMed: 10875232]

60. Zhao AZ, Huan JN, Gupta S, Pal R, Sahu A. A phosphatidylinositol 3-kinase phosphodiesterase 3B-cyclic AMP pathway in hypothalamic action of leptin on feeding. Nat Neurosci. 2002; 5(8): 727-728. [PubMed: 12101402]

61. Xu AW, Kaelin CB, Takeda K, Akira S, Schwartz MW, Barsh GS. PI3K integrates the action of insulin and leptin on hypothalamic neurons. J Clin Invest. 2005; 115(4):951-958. [PubMed: 15761497]

62. Lin X, Taguchi A, Park S, Kushner JA, Li F, Li Y, White MF. Dysregulation of insulin receptor substrate 2 in beta cells and brain causes obesity and diabetes. J Clin Invest. 2004; 114(7):908916. [PubMed: 15467829]

63. Kubota N, Terauchi Y, Tobe K, Yano W, Suzuki R, Ueki K, Takamoto I, Satoh H, Maki T, Kubota T, Moroi M, Okada-Iwabu M, Ezaki O, Nagai R, Ueta Y, Kadowaki T, Noda T. Insulin receptor substrate 2 plays a crucial role in beta cells and the hypothalamus. J Clin Invest. 2004; 114(7): 917-927. [PubMed: 15467830]

64. Duan C, Li M, Rui L. SH2-B promotes insulin receptor substrate 1 (IRS1)- and IRS2-mediated activation of the phosphatidylinositol 3-kinase pathway in response to leptin. J Biol Chem. 2004; 279(42):43684-43691. [PubMed: 15316008]

65. Ren D, Li M, Duan C, Rui L. Identification of SH2-B as a key regulator of leptin sensitivity, energy balance, and body weight in mice. Cell Metab. 2005; 2(2):95-104. [PubMed: 16098827]

66. Ren D, Zhou Y, Morris D, Li M, Li Z, Rui L. Neuronal SH2B1 is essential for controlling energy and glucose homeostasis. J Clin Invest. 2007; 117(2):397-406. [PubMed: 17235396]

67. Taniguchi CM, Emanuelli B, Kahn CR. Critical nodes in signalling pathways: insights into insulin action. Nat Rev Mol Cell Biol. 2006; 7(2):85-96. [PubMed: 16493415]

68. Kim MS, Pak YK, Jang PG, Namkoong C, Choi YS, Won JC, Kim KS, Kim SW, Kim HS, Park JY, Kim YB, Lee KU. Role of hypothalamic Foxo1 in the regulation of food intake and energy homeostasis. Nat Neurosci. 2006; 9(7):901-906. [PubMed: 16783365] 
69. Kitamura T, Feng Y, Kitamura YI, Chua SC Jr, Xu AW, Barsh GS, Rossetti L, Accili D. Forkhead protein FoxO1 mediates Agrp-dependent effects of leptin on food intake. Nat Med. 2006; 12(5): 534-540. [PubMed: 16604086]

70. Plum L, Lin HV, Dutia R, Tanaka J, Aizawa KS, Matsumoto M, Kim AJ, Cawley NX, Paik JH, Loh YP, DePinho RA, Wardlaw SL, Accili D. The obesity susceptibility gene Cpe links FoxO1 signaling in hypothalamic pro-opiomelanocortin neurons with regulation of food intake. Nat Med. 2009; 15(10):1195-1201. [PubMed: 19767734]

71. Sadagurski M, Leshan RL, Patterson C, Rozzo A, Kuznetsova A, Skorupski J, Jones JC, Depinho RA, Myers MG Jr, White MF. IRS2 signaling in LepR-b neurons suppresses FoxO1 to control energy balance independently of leptin action. Cell Metab. 2012; 15(5):703-712. [PubMed: 22560222]

72. Yang G, Lim CY, Li C, Xiao X, Radda GK, Cao X, Han W. FoxO1 inhibits leptin regulation of pro-opiomelanocortin promoter activity by blocking STAT3 interaction with specificity protein 1. J Biol Chem. 2009; 284(6):3719-3727. [PubMed: 19049975]

73. Cota D, Proulx K, Smith KA, Kozma SC, Thomas G, Woods SC, Seeley RJ. Hypothalamic mTOR signaling regulates food intake. Science. 2006; 312(5775):927-930. [PubMed: 16690869]

74. Maya-Monteiro CM, Bozza PT. Leptin and mTOR: partners in metabolism and inflammation. Cell Cycle. 2008; 7(12):1713-1717. [PubMed: 18583936]

75. Blouet C, Ono H, Schwartz GJ. Mediobasal hypothalamic p70 S6 kinase 1 modulates the control of energy homeostasis. Cell Metab. 2008; 8(6):459-467. [PubMed: 19041762]

76. Minokoshi Y, Alquier T, Furukawa N, Kim YB, Lee A, Xue B, Mu J, Foufelle F, Ferre P, Birnbaum MJ, Stuck BJ, Kahn BB. AMP-kinase regulates food intake by responding to hormonal and nutrient signals in the hypothalamus. Nature. 2004; 428(6982):569-574. [PubMed: 15058305]

77. Dagon Y, Hur E, Zheng B, Wellenstein K, Cantley LC, Kahn BB. p70S6 kinase phosphorylates AMPK on serine 491 to mediate leptin's effect on food intake. Cell Metab. 2012; 16(1):104-112. [PubMed: 22727014]

78. Su H, Jiang L, Carter-Su C, Rui L. Glucose enhances leptin signaling through modulation of AMPK activity. PLoS One. 2012; 7(2):e31636. [PubMed: 22359610]

79. Donato J Jr, Silva RJ, Sita LV, Lee S, Lee C, Lacchini S, Bittencourt JC, Franci CR, Canteras NS, Elias CF. The ventral premammillary nucleus links fasting-induced changes in leptin levels and coordinated luteinizing hormone secretion. J Neurosci. 2009; 29(16):5240-5250. [PubMed: 19386920]

80. Leinninger GM, Jo YH, Leshan RL, Louis GW, Yang H, Barrera JG, Wilson H, Opland DM, Faouzi MA, Gong Y, Jones JC, Rhodes CJ, Chua S Jr, Diano S, Horvath TL, Seeley RJ, Becker JB, Munzberg H, Myers MG Jr. Leptin acts via leptin receptor-expressing lateral hypothalamic neurons to modulate the mesolimbic dopamine system and suppress feeding. Cell Metab. 2009; 10(2):89-98. [PubMed: 19656487]

81. Mercer JG, Hoggard N, Williams LM, Lawrence CB, Hannah LT, Trayhurn P. Localization of leptin receptor mRNA and the long form splice variant $(\mathrm{Ob}-\mathrm{Rb})$ in mouse hypothalamus and adjacent brain regions by in situ hybridization. FEBS Lett. 1996; 387(2-3):113-116. [PubMed: 8674530]

82. Ring LE, Zeltser LM. Disruption of hypothalamic leptin signaling in mice leads to early-onset obesity, but physiological adaptations in mature animals stabilize adiposity levels. J Clin Invest. 2010; 120(8):2931-2941. [PubMed: 20592471]

83. Pan W, Hsuchou H, Jayaram B, Khan RS, Huang EY, Wu X, Chen C, Kastin AJ. Leptin action on nonneuronal cells in the CNS: potential clinical applications. Ann N Y Acad Sci. 2012; 1264(1): 64-71. [PubMed: 22530983]

84. Morton GJ, Niswender KD, Rhodes CJ, Myers MG Jr, Blevins JE, Baskin DG, Schwartz MW. Arcuate nucleus-specific leptin receptor gene therapy attenuates the obesity phenotype of Koletsky $(\mathrm{fa}(\mathrm{k}) / \mathrm{fa}(\mathrm{k}))$ rats. Endocrinology. 2003; 144(5):2016-2024. [PubMed: 12697710]

85. Myers MG Jr, Munzberg H, Leinninger GM, Leshan RL. The geometry of leptin action in the brain: more complicated than a simple ARC. Cell Metab. 2009; 9(2):117-123. [PubMed: 19187770] 
86. Elias CF, Lee C, Kelly J, Aschkenasi C, Ahima RS, Couceyro PR, Kuhar MJ, Saper CB, Elmquist JK. Leptin activates hypothalamic CART neurons projecting to the spinal cord. Neuron. 1998; 21(6):1375-1385. [PubMed: 9883730]

87. Balthasar N, Coppari R, McMinn J, Liu SM, Lee CE, Tang V, Kenny CD, McGovern RA, Chua SC Jr, Elmquist JK, Lowell BB. Leptin receptor signaling in POMC neurons is required for normal body weight homeostasis. Neuron. 2004; 42(6):983-991. [PubMed: 15207242]

88. Cowley MA, Smart JL, Rubinstein M, Cerdan MG, Diano S, Horvath TL, Cone RD, Low MJ. Leptin activates anorexigenic POMC neurons through a neural network in the arcuate nucleus. Nature. 2001; 411(6836):480-484. [PubMed: 11373681]

89. Fan W, Boston BA, Kesterson RA, Hruby VJ, Cone RD. Role of melanocortinergic neurons in feeding and the agouti obesity syndrome. Nature. 1997; 385(6612):165-168. [PubMed: 8990120]

90. Schwartz MW, Seeley RJ, Woods SC, Weigle DS, Campfield LA, Burn P, Baskin DG. Leptin increases hypothalamic pro-opiomelanocortin mRNA expression in the rostral arcuate nucleus. Diabetes. 1997; 46(12):2119-2123. [PubMed: 9392508]

91. Hillebrand JJ, de Wied D, Adan RA. Neuropeptides, food intake and body weight regulation: a hypothalamic focus. Peptides. 2002; 23(12):2283-2306. [PubMed: 12535710]

92. Butler AA, Cone RD. The melanocortin receptors: lessons from knockout models. Neuropeptides. 2002; 36(2-3):77-84. [PubMed: 12359499]

93. Huszar D, Lynch CA, Fairchild-Huntress V, Dunmore JH, Fang Q, Berkemeier LR, Gu W, Kesterson RA, Boston BA, Cone RD, Smith FJ, Campfield LA, Burn P, Lee F. Targeted disruption of the melanocortin-4 receptor results in obesity in mice. Cell. 1997; 88(1):131-141. [PubMed: 9019399]

94. Butler AA, Kesterson RA, Khong K, Cullen MJ, Pelleymounter MA, Dekoning J, Baetscher M, Cone RD. A unique metabolic syndrome causes obesity in the melanocortin-3 receptor-deficient mouse. Endocrinology. 2000; 141(9):3518-3521. [PubMed: 10965927]

95. Krude H, Biebermann H, Luck W, Horn R, Brabant G, Gruters A. Severe early-onset obesity, adrenal insufficiency and red hair pigmentation caused by POMC mutations in humans. Nat Genet. 1998; 19(2):155-157. [PubMed: 9620771]

96. Speliotes EK, Willer CJ, Berndt SI, Monda KL, Thorleifsson G, Jackson AU, Lango Allen H, Lindgren CM, Luan J, Magi R, Randall JC, Vedantam S, Winkler TW, Qi L, Workalemahu T, Heid IM, Steinthorsdottir V, Stringham HM, Weedon MN, Wheeler E, Wood AR, Ferreira T, Weyant RJ, Segre AV, Estrada K, Liang L, Nemesh J, Park JH, Gustafsson S, Kilpelainen TO, Yang J, Bouatia-Naji N, Esko T, Feitosa MF, Kutalik Z, Mangino M, Raychaudhuri S, Scherag A, Smith AV, Welch R, Zhao JH, Aben KK, Absher DM, Amin N, Dixon AL, Fisher E, Glazer NL, Goddard ME, Heard-Costa NL, Hoesel V, Hottenga JJ, Johansson A, Johnson T, Ketkar S, Lamina C, Li S, Moffatt MF, Myers RH, Narisu N, Perry JR, Peters MJ, Preuss M, Ripatti S, Rivadeneira F, Sandholt C, Scott LJ, Timpson NJ, Tyrer JP, van Wingerden S, Watanabe RM, White CC, Wiklund F, Barlassina C, Chasman DI, Cooper MN, Jansson JO, Lawrence RW, Pellikka N, Prokopenko I, Shi J, Thiering E, Alavere H, Alibrandi MT, Almgren P, Arnold AM, Aspelund T, Atwood LD, Balkau B, Balmforth AJ, Bennett AJ, Ben-Shlomo Y, Bergman RN, Bergmann S, Biebermann H, Blakemore AI, Boes T, Bonnycastle LL, Bornstein SR, Brown MJ, Buchanan TA, Busonero F, Campbell H, Cappuccio FP, Cavalcanti-Proenca C, Chen YD, Chen CM, Chines PS, Clarke R, Coin L, Connell J, Day IN, den Heijer M, Duan J, Ebrahim S, Elliott P, Elosua R, Eiriksdottir G, Erdos MR, Eriksson JG, Facheris MF, Felix SB, Fischer-Posovszky P, Folsom AR, Friedrich N, Freimer NB, Fu M, Gaget S, Gejman PV, Geus EJ, Gieger C, Gjesing AP, Goel A, Goyette P, Grallert H, Grassler J, Greenawalt DM, Groves CJ, Gudnason V, Guiducci C, Hartikainen AL, Hassanali N, Hall AS, Havulinna AS, Hayward C, Heath AC, Hengstenberg C, Hicks AA, Hinney A, Hofman A, Homuth G, Hui J, Igl W, Iribarren C, Isomaa B, Jacobs KB, Jarick I, Jewell E, John U, Jorgensen T, Jousilahti P, Jula A, Kaakinen M, Kajantie E, Kaplan LM, Kathiresan S, Kettunen J, Kinnunen L, Knowles JW, Kolcic I, Konig IR, Koskinen S, Kovacs P, Kuusisto J, Kraft P, Kvaloy K, Laitinen J, Lantieri O, Lanzani C, Launer LJ, Lecoeur C, Lehtimaki T, Lettre G, Liu J, Lokki ML, Lorentzon M, Luben RN, Ludwig B, Manunta P, Marek D, Marre M, Martin NG, McArdle WL, McCarthy A, McKnight B, Meitinger T, Melander O, Meyre D, Midthjell K, Montgomery GW, Morken MA, Morris AP, Mulic R, Ngwa JS, Nelis M, Neville MJ, Nyholt DR, O'Donnell CJ, O'Rahilly S, Ong KK, Oostra B, Pare G, Parker AN, Perola M, Pichler I, Pietilainen KH, Platou CG, Polasek O, Pouta A, Rafelt S, Raitakari O, Rayner NW, Ridderstrale 
M, Rief W, Ruokonen A, Robertson NR, Rzehak P, Salomaa V, Sanders AR, Sandhu MS, Sanna S, Saramies J, Savolainen MJ, Scherag S, Schipf S, Schreiber S, Schunkert H, Silander K, Sinisalo J, Siscovick DS, Smit JH, Soranzo N, Sovio U, Stephens J, Surakka I, Swift AJ, Tammesoo ML, Tardif JC, Teder-Laving M, Teslovich TM, Thompson JR, Thomson B, Tonjes A, Tuomi T, van Meurs JB, van Ommen GJ, Vatin V, Viikari J, Visvikis-Siest S, Vitart V, Vogel CI, Voight BF, Waite LL, Wallaschofski H, Walters GB, Widen E, Wiegand S, Wild SH, Willemsen G, Witte DR, Witteman JC, Xu J, Zhang Q, Zgaga L, Ziegler A, Zitting P, Beilby JP, Farooqi IS, Hebebrand J, Huikuri HV, James AL, Kahonen M, Levinson DF, Macciardi F, Nieminen MS, Ohlsson C, Palmer LJ, Ridker PM, Stumvoll M, Beckmann JS, Boeing H, Boerwinkle E, Boomsma DI, Caulfield MJ, Chanock SJ, Collins FS, Cupples LA, Smith GD, Erdmann J, Froguel P, Gronberg H, Gyllensten U, Hall P, Hansen T, Harris TB, Hattersley AT, Hayes RB, Heinrich J, Hu FB, Hveem K, Illig T, Jarvelin MR, Kaprio J, Karpe F, Khaw KT, Kiemeney LA, Krude H, Laakso M, Lawlor DA, Metspalu A, Munroe PB, Ouwehand WH, Pedersen O, Penninx BW, Peters A, Pramstaller PP, Quertermous T, Reinehr T, Rissanen A, Rudan I, Samani NJ, Schwarz PE, Shuldiner AR, Spector TD, Tuomilehto J, Uda M, Uitterlinden A, Valle TT, Wabitsch M, Waeber G, Wareham NJ, Watkins H, Wilson JF, Wright AF, Zillikens MC, Chatterjee N, McCarroll SA, Purcell S, Schadt EE, Visscher PM, Assimes TL, Borecki IB, Deloukas P, Fox CS, Groop LC, Haritunians T, Hunter DJ, Kaplan RC, Mohlke KL, O'Connell JR, Peltonen L, Schlessinger D, Strachan DP, van Duijn CM, Wichmann HE, Frayling TM, Thorsteinsdottir U, Abecasis GR, Barroso I, Boehnke M, Stefansson K, North KE, McCarthy MI, Hirschhorn JN, Ingelsson E, Loos RJ. Association analyses of 249,796 individuals reveal 18 new loci associated with body mass index. Nat Genet. 2010; 42(11):937-948. [PubMed: 20935630]

97. Loos RJ, Lindgren CM, Li S, Wheeler E, Zhao JH, Prokopenko I, Inouye M, Freathy RM, Attwood AP, Beckmann JS, Berndt SI, Jacobs KB, Chanock SJ, Hayes RB, Bergmann S, Bennett AJ, Bingham SA, Bochud M, Brown M, Cauchi S, Connell JM, Cooper C, Smith GD, Day I, Dina C, De S, Dermitzakis ET, Doney AS, Elliott KS, Elliott P, Evans DM, Sadaf Farooqi I, Froguel P, Ghori J, Groves CJ, Gwilliam R, Hadley D, Hall AS, Hattersley AT, Hebebrand J, Heid IM, Lamina C, Gieger C, Illig T, Meitinger T, Wichmann HE, Herrera B, Hinney A, Hunt SE, Jarvelin MR, Johnson T, Jolley JD, Karpe F, Keniry A, Khaw KT, Luben RN, Mangino M, Marchini J, McArdle WL, McGinnis R, Meyre D, Munroe PB, Morris AD, Ness AR, Neville MJ, Nica AC, Ong KK, O'Rahilly S, Owen KR, Palmer CN, Papadakis K, Potter S, Pouta A, Qi L, Randall JC, Rayner NW, Ring SM, Sandhu MS, Scherag A, Sims MA, Song K, Soranzo N, Speliotes EK, Syddall HE, Teichmann SA, Timpson NJ, Tobias JH, Uda M, Vogel CI, Wallace C, Waterworth DM, Weedon MN, Willer CJ, Wraight, Yuan X, Zeggini E, Hirschhorn JN, Strachan DP, Ouwehand WH, Caulfield MJ, Samani NJ, Frayling TM, Vollenweider P, Waeber G, Mooser V, Deloukas P, McCarthy MI, Wareham NJ, Barroso I, Kraft P, Hankinson SE, Hunter DJ, Hu FB, Lyon HN, Voight BF, Ridderstrale M, Groop L, Scheet P, Sanna S, Abecasis GR, Albai G, Nagaraja R, Schlessinger D, Jackson AU, Tuomilehto J, Collins FS, Boehnke M, Mohlke KL. Common variants near MC4R are associated with fat mass, weight and risk of obesity. Nat Genet. 2008; 40(6):768-775. [PubMed: 18454148]

98. Hahn TM, Breininger JF, Baskin DG, Schwartz MW. Coexpression of Agrp and NPY in fastingactivated hypothalamic neurons. Nat Neurosci. 1998; 1(4):271-272. [PubMed: 10195157]

99. Luo N, Marcelin G, Liu SM, Schwartz G, Chua S Jr. Neuropeptide Y and agouti-related peptide mediate complementary functions of hyperphagia and reduced energy expenditure in leptin receptor deficiency. Endocrinology. 2011; 152(3):883-889. [PubMed: 21285324]

100. Gropp E, Shanabrough M, Borok E, Xu AW, Janoschek R, Buch T, Plum L, Balthasar N, Hampel B, Waisman A, Barsh GS, Horvath TL, Bruning JC. Agouti-related peptide-expressing neurons are mandatory for feeding. Nat Neurosci. 2005; 8(10):1289-1291. [PubMed: 16158063]

101. Luquet S, Perez FA, Hnasko TS, Palmiter RD. NPY/AgRP neurons are essential for feeding in adult mice but can be ablated in neonates. Science. 2005; 310(5748):683-685. [PubMed: 16254186]

102. Bewick GA, Gardiner JV, Dhillo WS, Kent AS, White NE, Webster Z, Ghatei MA, Bloom SR. Post-embryonic ablation of AgRP neurons in mice leads to a lean, hypophagic phenotype. FASEB J. 2005; 19(12):1680-1682. [PubMed: 16099943]

103. Aponte Y, Atasoy D, Sternson SM. AGRP neurons are sufficient to orchestrate feeding behavior rapidly and without training. Nat Neurosci. 2011; 14(3):351-355. [PubMed: 21209617] 
104. Ollmann MM, Wilson BD, Yang YK, Kerns JA, Chen Y, Gantz I, Barsh GS. Antagonism of central melanocortin receptors in vitro and in vivo by agouti-related protein. Science. 1997; 278(5335):135-138. [PubMed: 9311920]

105. Qian S, Chen H, Weingarth D, Trumbauer ME, Novi DE, Guan X, Yu H, Shen Z, Feng Y, Frazier E, Chen A, Camacho RE, Shearman LP, Gopal-Truter S, MacNeil DJ, Van der Ploeg LH, Marsh DJ. Neither agouti-related protein nor neuropeptide $\mathrm{Y}$ is critically required for the regulation of energy homeostasis in mice. Mol Cell Biol. 2002; 22(14):5027-5035. [PubMed: 12077332]

106. Tong Q, Ye CP, Jones JE, Elmquist JK, Lowell BB. Synaptic release of GABA by AgRP neurons is required for normal regulation of energy balance. Nat Neurosci. 2008; 11(9):998-1000. [PubMed: 19160495]

107. van de Wall E, Leshan R, Xu AW, Balthasar N, Coppari R, Liu SM, Jo YH, MacKenzie RG, Allison DB, Dun NJ, Elmquist J, Lowell BB, Barsh GS, de Luca C, Myers MG Jr, Schwartz GJ, Chua SC Jr. Collective and individual functions of leptin receptor modulated neurons controlling metabolism and ingestion. Endocrinology. 2008; 149(4):1773-1785. [PubMed: 18162515]

108. Coppari R, Ichinose M, Lee CE, Pullen AE, Kenny CD, McGovern RA, Tang V, Liu SM, Ludwig T, Chua SC Jr, Lowell BB, Elmquist JK. The hypothalamic arcuate nucleus: a key site for mediating leptin's effects on glucose homeostasis and locomotor activity. Cell Metab. 2005; 1(1): 63-72. [PubMed: 16054045]

109. Morton GJ, Gelling RW, Niswender KD, Morrison CD, Rhodes CJ, Schwartz MW. Leptin regulates insulin sensitivity via phosphatidylinositol-3-OH kinase signaling in mediobasal hypothalamic neurons. Cell Metab. 2005; 2(6):411-420. [PubMed: 16330326]

110. Vong L, Ye C, Yang Z, Choi B, Chua S Jr, Lowell BB. Leptin action on GABAergic neurons prevents obesity and reduces inhibitory tone to POMC neurons. Neuron. 2011; 71(1):142-154. [PubMed: 21745644]

111. Leshan RL, Greenwald-Yarnell M, Patterson CM, Gonzalez IE, Myers MG Jr. Leptin action through hypothalamic nitric oxide synthase-1-expressing neurons controls energy balance. Nat Med. 2012; 18(5):820-823. [PubMed: 22522563]

112. Harris M, Aschkenasi C, Elias CF, Chandrankunnel A, Nillni EA, Bjoorbaek C, Elmquist JK, Flier JS, Hollenberg AN. Transcriptional regulation of the thyrotropin-releasing hormone gene by leptin and melanocortin signaling. J Clin Invest. 2001; 107(1):111-120. [PubMed: 11134186]

113. Kim MS, Small CJ, Stanley SA, Morgan DG, Seal LJ, Kong WM, Edwards CM, Abusnana S, Sunter D, Ghatei MA, Bloom SR. The central melanocortin system affects the hypothalamopituitary thyroid axis and may mediate the effect of leptin. J Clin Invest. 2000; 105(7):10051011. [PubMed: 10749579]

114. Balthasar N, Dalgaard LT, Lee CE, Yu J, Funahashi H, Williams T, Ferreira M, Tang V, McGovern RA, Kenny CD, Christiansen LM, Edelstein E, Choi B, Boss O, Aschkenasi C, Zhang CY, Mountjoy K, Kishi T, Elmquist JK, Lowell BB. Divergence of melanocortin pathways in the control of food intake and energy expenditure. Cell. 2005; 123(3):493-505. [PubMed: 16269339]

115. Ghamari-Langroudi M, Srisai D, Cone RD. Multinodal regulation of the arcuate/paraventricular nucleus circuit by leptin. Proc Natl Acad Sci U S A. 2011; 108(1):355-360. [PubMed: 21169216]

116. Xu B, Goulding EH, Zang K, Cepoi D, Cone RD, Jones KR, Tecott LH, Reichardt LF. Brainderived neurotrophic factor regulates energy balance downstream of melanocortin-4 receptor. Nat Neurosci. 2003; 6(7):736-742. [PubMed: 12796784]

117. Sternson SM, Shepherd GM, Friedman JM. Topographic mapping of VMH --> arcuate nucleus microcircuits and their reorganization by fasting. Nat Neurosci. 2005; 8(10):1356-1363. [PubMed: 16172601]

118. Yadav VK, Oury F, Suda N, Liu ZW, Gao XB, Confavreux C, Klemenhagen KC, Tanaka KF, Gingrich JA, Guo XE, Tecott LH, Mann JJ, Hen R, Horvath TL, Karsenty G. A serotonindependent mechanism explains the leptin regulation of bone mass, appetite, and energy expenditure. Cell. 2009; 138(5):976-989. [PubMed: 19737523]

119. Morris DL, Cho KW, Rui L. Critical role of the Src homology 2 (SH2) domain of neuronal SH2B1 in the regulation of body weight and glucose homeostasis in mice. Endocrinology. 2010; 151(8):3643-3651. [PubMed: 20484460] 
120. Coppari R, Bjorbaek C. Leptin revisited: its mechanism of action and potential for treating diabetes. Nat Rev Drug Discov. 2012; 11(9):692-708. [PubMed: 22935803]

121. Banks WA, Kastin AJ, Huang W, Jaspan JB, Maness LM. Leptin enters the brain by a saturable system independent of insulin. Peptides. 1996; 17(2):305-311. [PubMed: 8801538]

122. Hileman SM, Pierroz DD, Masuzaki H, Bjorbaek C, El-Haschimi K, Banks WA, Flier JS. Characterizaton of short isoforms of the leptin receptor in rat cerebral microvessels and of brain uptake of leptin in mouse models of obesity. Endocrinology. 2002; 143(3):775-783. [PubMed: 11861497]

123. Kastin AJ, Pan W, Maness LM, Koletsky RJ, Ernsberger P. Decreased transport of leptin across the blood-brain barrier in rats lacking the short form of the leptin receptor. Peptides. 1999; 20(12):1449-1453. [PubMed: 10698121]

124. Tu H, Kastin AJ, Hsuchou H, Pan W. Soluble receptor inhibits leptin transport. J Cell Physiol. 2008; 214(2):301-305. [PubMed: 17620316]

125. El-Haschimi K, Pierroz DD, Hileman SM, Bjorbaek C, Flier JS. Two defects contribute to hypothalamic leptin resistance in mice with diet-induced obesity. J Clin Invest. 2000; 105(12): 1827-1832. [PubMed: 10862798]

126. Caro JF, Kolaczynski JW, Nyce MR, Ohannesian JP, Opentanova I, Goldman WH, Lynn RB, Zhang PL, Sinha MK, Considine RV. Decreased cerebrospinal-fluid/serum leptin ratio in obesity: a possible mechanism for leptin resistance. Lancet. 1996; 348(9021):159-161. [PubMed: 8684156]

127. Banks WA, DiPalma CR, Farrell CL. Impaired transport of leptin across the blood-brain barrier in obesity. Peptides. 1999; 20(11):1341-1345. [PubMed: 10612449]

128. Herde MK, Geist K, Campbell RE, Herbison AE. Gonadotropin-releasing hormone neurons extend complex highly branched dendritic trees outside the blood-brain barrier. Endocrinology. 2011; 152(10):3832-3841. [PubMed: 21791557]

129. Banks WA, Farrell CL. Impaired transport of leptin across the blood-brain barrier in obesity is acquired and reversible. Am J Physiol Endocrinol Metab. 2003; 285(1):E10-E15. [PubMed: 12618361]

130. Belouzard S, Delcroix D, Rouille Y. Low levels of expression of leptin receptor at the cell surface result from constitutive endocytosis and intracellular retention in the biosynthetic pathway. J Biol Chem. 2004; 279(27):28499-28508. [PubMed: 15123629]

131. Diano S, Kalra SP, Horvath TL. Leptin receptor immunoreactivity is associated with the Golgi apparatus of hypothalamic neurons and glial cells. J Neuroendocrinol. 1998; 10(9):647-650. [PubMed: 9744481]

132. Seo S, Guo DF, Bugge K, Morgan DA, Rahmouni K, Sheffield VC. Requirement of Bardet-Biedl syndrome proteins for leptin receptor signaling. Hum Mol Genet. 2009; 18(7):1323-1331. [PubMed: 19150989]

133. Rahmouni K, Fath MA, Seo S, Thedens DR, Berry CJ, Weiss R, Nishimura DY, Sheffield VC. Leptin resistance contributes to obesity and hypertension in mouse models of Bardet-Biedl syndrome. J Clin Invest. 2008; 118(4):1458-1467. [PubMed: 18317593]

134. Bjorbaek C, Elmquist JK, Frantz JD, Shoelson SE, Flier JS. Identification of SOCS-3 as a potential mediator of central leptin resistance. Mol Cell. 1998; 1(4):619-625. [PubMed: 9660946]

135. Kaszubska W, Falls HD, Schaefer VG, Haasch D, Frost L, Hessler P, Kroeger PE, White DW, Jirousek MR, Trevillyan JM. Protein tyrosine phosphatase 1B negatively regulates leptin signaling in a hypothalamic cell line. Mol Cell Endocrinol. 2002; 195(1-2):109-118. [PubMed: 12354677]

136. Loh K, Fukushima A, Zhang X, Galic S, Briggs D, Enriori PJ, Simonds S, Wiede F, Reichenbach A, Hauser C, Sims NA, Bence KK, Zhang S, Zhang ZY, Kahn BB, Neel BG, Andrews ZB, Cowley MA, Tiganis T. Elevated hypothalamic TCPTP in obesity contributes to cellular leptin resistance. Cell Metab. 2011; 14(5):684-699. [PubMed: 22000926]

137. Gamber KM, Huo L, Ha S, Hairston JE, Greeley S, Bjorbaek C. Over-expression of leptin receptors in hypothalamic POMC neurons increases susceptibility to diet-induced obesity. PLoS One. 2012; 7(1):e30485. [PubMed: 22276206] 
138. Bjorbaek C, El-Haschimi K, Frantz JD, Flier JS. The role of SOCS-3 in leptin signaling and leptin resistance. J Biol Chem. 1999; 274(42):30059-30065. [PubMed: 10514492]

139. Howard JK, Cave BJ, Oksanen LJ, Tzameli I, Bjorbaek C, Flier JS. Enhanced leptin sensitivity and attenuation of diet-induced obesity in mice with haploinsufficiency of Socs3. Nat Med. 2004; 10(7):734-738. [PubMed: 15220914]

140. Mori H, Hanada R, Hanada T, Aki D, Mashima R, Nishinakamura H, Torisu T, Chien KR, Yasukawa H, Yoshimura A. Socs3 deficiency in the brain elevates leptin sensitivity and confers resistance to diet-induced obesity. Nat Med. 2004; 10(7):739-743. [PubMed: 15208705]

141. Peralta S, Carrascosa JM, Gallardo N, Ros M, Arribas C. Ageing increases SOCS-3 expression in rat hypothalamus: effects of food restriction. Biochem Biophys Res Commun. 2002; 296(2):425428. [PubMed: 12163036]

142. Reed AS, Unger EK, Olofsson LE, Piper ML, Myers MG Jr, Xu AW. Functional role of suppressor of cytokine signaling 3 upregulation in hypothalamic leptin resistance and long-term energy homeostasis. Diabetes. 2010; 59(4):894-906. [PubMed: 20068134]

143. Zabolotny JM, Bence-Hanulec KK, Stricker-Krongrad A, Haj F, Wang Y, Minokoshi Y, Kim YB, Elmquist JK, Tartaglia LA, Kahn BB, Neel BG. PTP1B regulates leptin signal transduction in vivo. Dev Cell. 2002; 2(4):489-495. [PubMed: 11970898]

144. Cheng A, Uetani N, Simoncic PD, Chaubey VP, Lee-Loy A, McGlade CJ, Kennedy BP, Tremblay ML. Attenuation of leptin action and regulation of obesity by protein tyrosine phosphatase 1B. Dev Cell. 2002; 2(4):497-503. [PubMed: 11970899]

145. Bence KK, Delibegovic M, Xue B, Gorgun CZ, Hotamisligil GS, Neel BG, Kahn BB. Neuronal PTP1B regulates body weight, adiposity and leptin action. Nat Med. 2006; 12(8):917-924. [PubMed: 16845389]

146. Tsou RC, Zimmer DJ, De Jonghe BC, Bence KK. Deficiency of PTP1B in Leptin ReceptorExpressing Neurons Leads to Decreased Body Weight and Adiposity in Mice. Endocrinology. 2012; 153(9):4227-4237. [PubMed: 22802463]

147. Banno R, Zimmer D, De Jonghe BC, Atienza M, Rak K, Yang W, Bence KK. PTP1B and SHP2 in POMC neurons reciprocally regulate energy balance in mice. J Clin Invest. 2010; 120(3):720734. [PubMed: 20160350]

148. Morrison CD, White CL, Wang Z, Lee SY, Lawrence DS, Cefalu WT, Zhang ZY, Gettys TW. Increased hypothalamic protein tyrosine phosphatase $1 \mathrm{~B}$ contributes to leptin resistance with age. Endocrinology. 2007; 148(1):433-440. [PubMed: 17038557]

149. White CL, Whittington A, Barnes MJ, Wang Z, Bray GA, Morrison CD. HF diets increase hypothalamic PTP1B and induce leptin resistance through both leptin-dependent and independent mechanisms. Am J Physiol Endocrinol Metab. 2009; 296(2):E291-E299. [PubMed: 19017730]

150. Rousso-Noori L, Knobler H, Levy-Apter E, Kuperman Y, Neufeld-Cohen A, Keshet Y, Akepati VR, Klinghoffer RA, Chen A, Elson A. Protein tyrosine phosphatase epsilon affects body weight by downregulating leptin signaling in a phosphorylation-dependent manner. Cell Metab. 2011; 13(5):562-572. [PubMed: 21531338]

151. Plum L, Rother E, Munzberg H, Wunderlich FT, Morgan DA, Hampel B, Shanabrough M, Janoschek R, Konner AC, Alber J, Suzuki A, Krone W, Horvath TL, Rahmouni K, Bruning JC. Enhanced leptin-stimulated Pi3k activation in the CNS promotes white adipose tissue transdifferentiation. Cell Metab. 2007; 6(6):431-445. [PubMed: 18054313]

152. Plum L, Ma X, Hampel B, Balthasar N, Coppari R, Munzberg H, Shanabrough M, Burdakov D, Rother E, Janoschek R, Alber J, Belgardt BF, Koch L, Seibler J, Schwenk F, Fekete C, Suzuki A, Mak TW, Krone W, Horvath TL, Ashcroft FM, Bruning JC. Enhanced PIP3 signaling in POMC neurons causes KATP channel activation and leads to diet-sensitive obesity. J Clin Invest. 2006; 116(7):1886-1901. [PubMed: 16794735]

153. Klockener T, Hess S, Belgardt BF, Paeger L, Verhagen LA, Husch A, Sohn JW, Hampel B, Dhillon H, Zigman JM, Lowell BB, Williams KW, Elmquist JK, Horvath TL, Kloppenburg P, Bruning JC. High-fat feeding promotes obesity via insulin receptor/PI3K-dependent inhibition of SF-1 VMH neurons. Nat Neurosci. 2011; 14(7):911-918. [PubMed: 21642975] 
154. Li Z, Zhou Y, Carter-Su C, Myers MG Jr, Rui L. SH2B1 enhances leptin signaling by both Janus kinase 2 Tyr813 phosphorylation-dependent and -independent mechanisms. Mol Endocrinol. 2007; 21(9):2270-2281. [PubMed: 17565041]

155. Rui L, Carter-Su C. Identification of SH2-bbeta as a potent cytoplasmic activator of the tyrosine kinase Janus kinase 2. Proc Natl Acad Sci U S A. 1999; 96(13):7172-7177. [PubMed: 10377387]

156. Morris DL, Cho KW, Zhou Y, Rui L. SH2B1 enhances insulin sensitivity by both stimulating the insulin receptor and inhibiting tyrosine dephosphorylation of insulin receptor substrate proteins. Diabetes. 2009; 58(9):2039-2047. [PubMed: 19542202]

157. Song W, Ren D, Li W, Jiang L, Cho KW, Huang P, Fan C, Song Y, Liu Y, Rui L. SH2B regulation of growth, metabolism, and longevity in both insects and mammals. Cell Metab. 2010; 11(5):427-437. [PubMed: 20417156]

158. Jamshidi Y, Snieder H, Ge D, Spector TD, O'Dell SD. The SH2B gene is associated with serum leptin and body fat in normal female twins. Obesity (Silver Spring). 2007; 15(1):5-9. [PubMed: 17228025]

159. Renstrom F, Payne F, Nordstrom A, Brito EC, Rolandsson O, Hallmans G, Barroso I, Nordstrom $\mathrm{P}$, Franks PW. Replication and extension of genome-wide association study results for obesity in 4923 adults from northern Sweden. Hum Mol Genet. 2009; 18(8):1489-1496. [PubMed: 19164386]

160. Hester JM, Wing MR, Li J, Palmer ND, Xu J, Hicks PJ, Roh BH, Norris JM, Wagenknecht LE, Langefeld CD, Freedman BI, Bowden DW, Ng MC. Implication of European-derived adiposity loci in African Americans. Int J Obes (Lond). 2012; 36(3):465-473. [PubMed: 21750520]

161. Willer CJ, Speliotes EK, Loos RJ, Li S, Lindgren CM, Heid IM, Berndt SI, Elliott AL, Jackson AU, Lamina C, Lettre G, Lim N, Lyon HN, McCarroll SA, Papadakis K, Qi L, Randall JC, Roccasecca RM, Sanna S, Scheet P, Weedon MN, Wheeler E, Zhao JH, Jacobs LC, Prokopenko I, Soranzo N, Tanaka T, Timpson NJ, Almgren P, Bennett A, Bergman RN, Bingham SA, Bonnycastle LL, Brown M, Burtt NP, Chines P, Coin L, Collins FS, Connell JM, Cooper C, Smith GD, Dennison EM, Deodhar P, Elliott P, Erdos MR, Estrada K, Evans DM, Gianniny L, Gieger C, Gillson CJ, Guiducci C, Hackett R, Hadley D, Hall AS, Havulinna AS, Hebebrand J, Hofman A, Isomaa B, Jacobs KB, Johnson T, Jousilahti P, Jovanovic Z, Khaw KT, Kraft P, Kuokkanen M, Kuusisto J, Laitinen J, Lakatta EG, Luan J, Luben RN, Mangino M, McArdle WL, Meitinger T, Mulas A, Munroe PB, Narisu N, Ness AR, Northstone K, O'Rahilly S, Purmann C, Rees MG, Ridderstrale M, Ring SM, Rivadeneira F, Ruokonen A, Sandhu MS, Saramies J, Scott LJ, Scuteri A, Silander K, Sims MA, Song K, Stephens J, Stevens S, Stringham HM, Tung YC, Valle TT, Van Duijn CM, Vimaleswaran KS, Vollenweider P, Waeber G, Wallace C, Watanabe RM, Waterworth DM, Watkins N, Witteman JC, Zeggini E, Zhai G, Zillikens MC, Altshuler D, Caulfield MJ, Chanock SJ, Farooqi IS, Ferrucci L, Guralnik JM, Hattersley AT, Hu FB, Jarvelin MR, Laakso M, Mooser V, Ong KK, Ouwehand WH, Salomaa V, Samani NJ, Spector TD, Tuomi T, Tuomilehto J, Uda M, Uitterlinden AG, Wareham NJ, Deloukas P, Frayling TM, Groop LC, Hayes RB, Hunter DJ, Mohlke KL, Peltonen L, Schlessinger D, Strachan DP, Wichmann HE, McCarthy MI, Boehnke M, Barroso I, Abecasis GR, Hirschhorn JN. Six new loci associated with body mass index highlight a neuronal influence on body weight regulation. Nat Genet. 2009; 41(1):25-34. [PubMed: 19079261]

162. Thorleifsson G, Walters GB, Gudbjartsson DF, Steinthorsdottir V, Sulem P, Helgadottir A, Styrkarsdottir U, Gretarsdottir S, Thorlacius S, Jonsdottir I, Jonsdottir T, Olafsdottir EJ, Olafsdottir GH, Jonsson T, Jonsson F, Borch-Johnsen K, Hansen T, Andersen G, Jorgensen T, Lauritzen T, Aben KK, Verbeek AL, Roeleveld N, Kampman E, Yanek LR, Becker LC, Tryggvadottir L, Rafnar T, Becker DM, Gulcher J, Kiemeney LA, Pedersen O, Kong A, Thorsteinsdottir U, Stefansson K. Genome-wide association yields new sequence variants at seven loci that associate with measures of obesity. Nat Genet. 2009; 41(1):18-24. [PubMed: 19079260]

163. Bochukova EG, Huang N, Keogh J, Henning E, Purmann C, Blaszczyk K, Saeed S, HamiltonShield J, Clayton-Smith J, O'Rahilly S, Hurles ME, Farooqi IS. Large, rare chromosomal deletions associated with severe early-onset obesity. Nature. 2010; 463(7281):666-670. [PubMed: 19966786] 
164. Farooqi IS, Keogh JM, Yeo GS, Lank EJ, Cheetham T, O'Rahilly S. Clinical spectrum of obesity and mutations in the melanocortin 4 receptor gene. N Engl J Med. 2003; 348(12):1085-1095. [PubMed: 12646665]

165. Lubrano-Berthelier C, Durand E, Dubern B, Shapiro A, Dazin P, Weill J, Ferron C, Froguel P, Vaisse C. Intracellular retention is a common characteristic of childhood obesity-associated MC4R mutations. Hum Mol Genet. 2003; 12(2):145-153. [PubMed: 12499395]

166. Marsh DJ, Hollopeter G, Huszar D, Laufer R, Yagaloff KA, Fisher SL, Burn P, Palmiter RD. Response of melanocortin-4 receptor-deficient mice to anorectic and orexigenic peptides. Nat Genet. 1999; 21(1):119-122. [PubMed: 9916804]

167. Yeo GS, Farooqi IS, Aminian S, Halsall DJ, Stanhope RG, O'Rahilly S. A frameshift mutation in MC4R associated with dominantly inherited human obesity. Nat Genet. 1998; 20(2):111-112. [PubMed: 9771698]

168. Pelleymounter MA, Cullen MJ, Wellman CL. Characteristics of BDNF-induced weight loss. Exp Neurol. 1995; 131(2):229-238. [PubMed: 7534721]

169. Yeo GS, Connie Hung CC, Rochford J, Keogh J, Gray J, Sivaramakrishnan S, O'Rahilly S, Farooqi IS. A de novo mutation affecting human TrkB associated with severe obesity and developmental delay. Nat Neurosci. 2004; 7(11):1187-1189. [PubMed: 15494731]

170. Liao GY, An JJ, Gharami K, Waterhouse EG, Vanevski F, Jones KR, Xu B. Dendritically targeted Bdnf mRNA is essential for energy balance and response to leptin. Nat Med. 2012; 18(4):564-571. [PubMed: 22426422]

171. Knight ZA, Hannan KS, Greenberg ML, Friedman JM. Hyperleptinemia is required for the development of leptin resistance. PLoS One. 2010; 5(6):e11376. [PubMed: 20613882]

172. Ernst MB, Wunderlich CM, Hess S, Paehler M, Mesaros A, Koralov SB, Kleinridders A, Husch A, Munzberg H, Hampel B, Alber J, Kloppenburg P, Bruning JC, Wunderlich FT. Enhanced Stat3 activation in POMC neurons provokes negative feedback inhibition of leptin and insulin signaling in obesity. J Neurosci. 2009; 29(37):11582-11593. [PubMed: 19759305]

173. Tam J, Cinar R, Liu J, Godlewski G, Wesley D, Jourdan T, Szanda G, Mukhopadhyay B, Chedester L, Liow JS, Innis RB, Cheng K, Rice KC, Deschamps JR, Chorvat RJ, McElroy JF, Kunos G. Peripheral cannabinoid-1 receptor inverse agonism reduces obesity by reversing leptin resistance. Cell Metab. 2012; 16(2):167-179. [PubMed: 22841573]

174. Gregor MF, Hotamisligil GS. Inflammatory mechanisms in obesity. Annu Rev Immunol. 2011; 29:415-445. [PubMed: 21219177]

175. De Souza CT, Araujo EP, Bordin S, Ashimine R, Zollner RL, Boschero AC, Saad MJ, Velloso LA. Consumption of a fat-rich diet activates a proinflammatory response and induces insulin resistance in the hypothalamus. Endocrinology. 2005; 146(10):4192-4199. [PubMed: 16002529]

176. Zhang X, Zhang G, Zhang H, Karin M, Bai H, Cai D. Hypothalamic IKKbeta/NF-kappaB and ER stress link overnutrition to energy imbalance and obesity. Cell. 2008; 135(1):61-73. [PubMed: 18854155]

177. Shi H, Kokoeva MV, Inouye K, Tzameli I, Yin H, Flier JS. TLR4 links innate immunity and fatty acid-induced insulin resistance. J Clin Invest. 2006; 116(11):3015-3025. [PubMed: 17053832]

178. Milanski M, Degasperi G, Coope A, Morari J, Denis R, Cintra DE, Tsukumo DM, Anhe G, Amaral ME, Takahashi HK, Curi R, Oliveira HC, Carvalheira JB, Bordin S, Saad MJ, Velloso LA. Saturated fatty acids produce an inflammatory response predominantly through the activation of TLR4 signaling in hypothalamus: implications for the pathogenesis of obesity. $\mathrm{J}$ Neurosci. 2009; 29(2):359-370. [PubMed: 19144836]

179. Kleinridders A, Schenten D, Konner AC, Belgardt BF, Mauer J, Okamura T, Wunderlich FT, Medzhitov R, Bruning JC. MyD88 signaling in the CNS is required for development of fatty acid-induced leptin resistance and diet-induced obesity. Cell Metab. 2009; 10(4):249-259. [PubMed: 19808018]

180. Hirosumi J, Tuncman G, Chang L, Gorgun CZ, Uysal KT, Maeda K, Karin M, Hotamisligil GS. A central role for JNK in obesity and insulin resistance. Nature. 2002; 420(6913):333-336. [PubMed: 12447443] 
181. Sabio G, Cavanagh-Kyros J, Barrett T, Jung DY, Ko HJ, Ong H, Morel C, Mora A, Reilly J, Kim JK, Davis RJ. Role of the hypothalamic-pituitary-thyroid axis in metabolic regulation by JNK1. Genes Dev. 2010; 24(3):256-264. [PubMed: 20080940]

182. Ron D, Walter P. Signal integration in the endoplasmic reticulum unfolded protein response. Nat Rev Mol Cell Biol. 2007; 8(7):519-529. [PubMed: 17565364]

183. Hotamisligil GS. Endoplasmic reticulum stress and the inflammatory basis of metabolic disease. Cell. 2010; 140(6):900-917. [PubMed: 20303879]

184. Ozcan L, Ergin AS, Lu A, Chung J, Sarkar S, Nie D, Myers MG Jr, Ozcan U. Endoplasmic reticulum stress plays a central role in development of leptin resistance. Cell Metab. 2009; 9(1): 35-51. [PubMed: 19117545]

185. Hosoi T, Sasaki M, Miyahara T, Hashimoto C, Matsuo S, Yoshii M, Ozawa K. Endoplasmic reticulum stress induces leptin resistance. Mol Pharmacol. 2008; 74(6):1610-1619. [PubMed: 18755873]

186. Won JC, Jang PG, Namkoong C, Koh EH, Kim SK, Park JY, Lee KU, Kim MS. Central administration of an endoplasmic reticulum stress inducer inhibits the anorexigenic effects of leptin and insulin. Obesity (Silver Spring). 2009; 17(10):1861-1865. [PubMed: 19543218]

187. Ropelle ER, Flores MB, Cintra DE, Rocha GZ, Pauli JR, Morari J, de Souza CT, Moraes JC, Prada PO, Guadagnini D, Marin RM, Oliveira AG, Augusto TM, Carvalho HF, Velloso LA, Saad MJ, Carvalheira JB. IL-6 and IL-10 anti-inflammatory activity links exercise to hypothalamic insulin and leptin sensitivity through IKKbeta and ER stress inhibition. PLoS Biol. 2010; 8(8)

188. Malik SA, Marino G, BenYounes A, Shen S, Harper F, Maiuri MC, Kroemer G. Neuroendocrine regulation of autophagy by leptin. Cell Cycle. 2011; 10(17):2917-2923. [PubMed: 21857156]

189. Meng Q, Cai D. Defective hypothalamic autophagy directs the central pathogenesis of obesity via the IkappaB kinase beta (IKKbeta)/NF-kappaB pathway. J Biol Chem. 2011; 286(37):3232432332. [PubMed: 21784844]

190. Kaushik S, Rodriguez-Navarro JA, Arias E, Kiffin R, Sahu S, Schwartz GJ, Cuervo AM, Singh R. Autophagy in hypothalamic AgRP neurons regulates food intake and energy balance. Cell Metab. 2011; 14(2):173-183. [PubMed: 21803288]

191. Quan W, Kim HK, Moon EY, Kim SS, Choi CS, Komatsu M, Jeong YT, Lee MK, Kim KW, Kim MS, Lee MS. Role of hypothalamic proopiomelanocortin neuron autophagy in the control of appetite and leptin response. Endocrinology. 2012; 153(4):1817-1826. [PubMed: 22334718] 


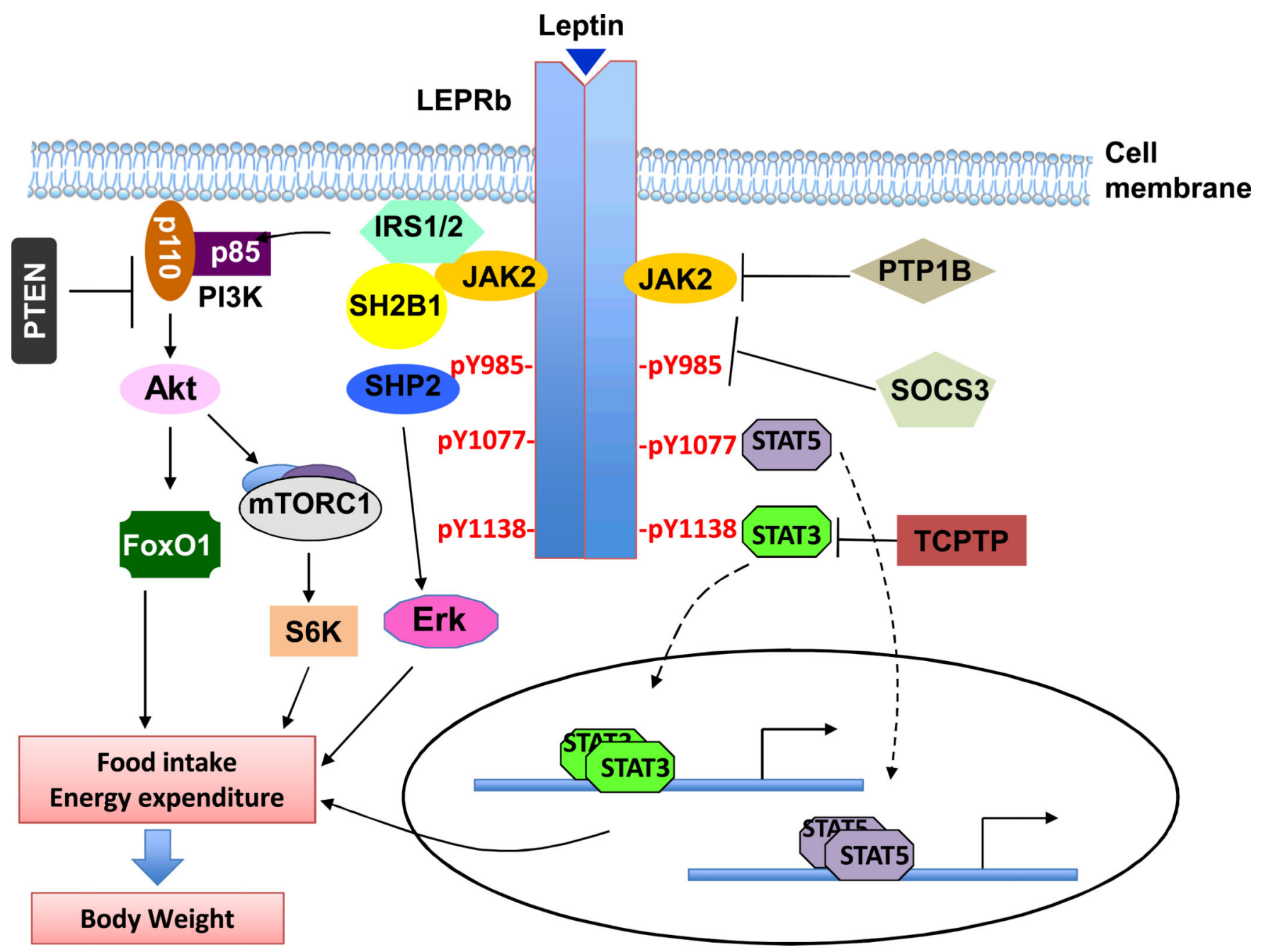

Fig. 1. Leptin signaling pathways

Leptin binds to LEPRb and activates JAK2. JAK2 phosphorylates LEPRb on Tyr ${ }^{985}$, $\mathrm{Tyr}^{1077}$ and Tyr ${ }^{1138}$. Phospho-Tyr ${ }^{985}$, -Tyr ${ }^{1077}$ and -Tyr ${ }^{138}$ bind to downstream molecules and activate the JAK2/STAT3, JAK2/STAT5, PI3K/IRS/AKT, and SHP2/ERK pathways. These pathways act coordinately to regulate energy balance and body weight. LEPRb signaling is regulated both negatively by SOCS3, PTP1B, TCPTP, PTEN and RPTPe and positively by SH2B1. Many factors, including hyperleptinemia, inflammation, ER stress, and defective autophagy, contribute to leptin resistance. 


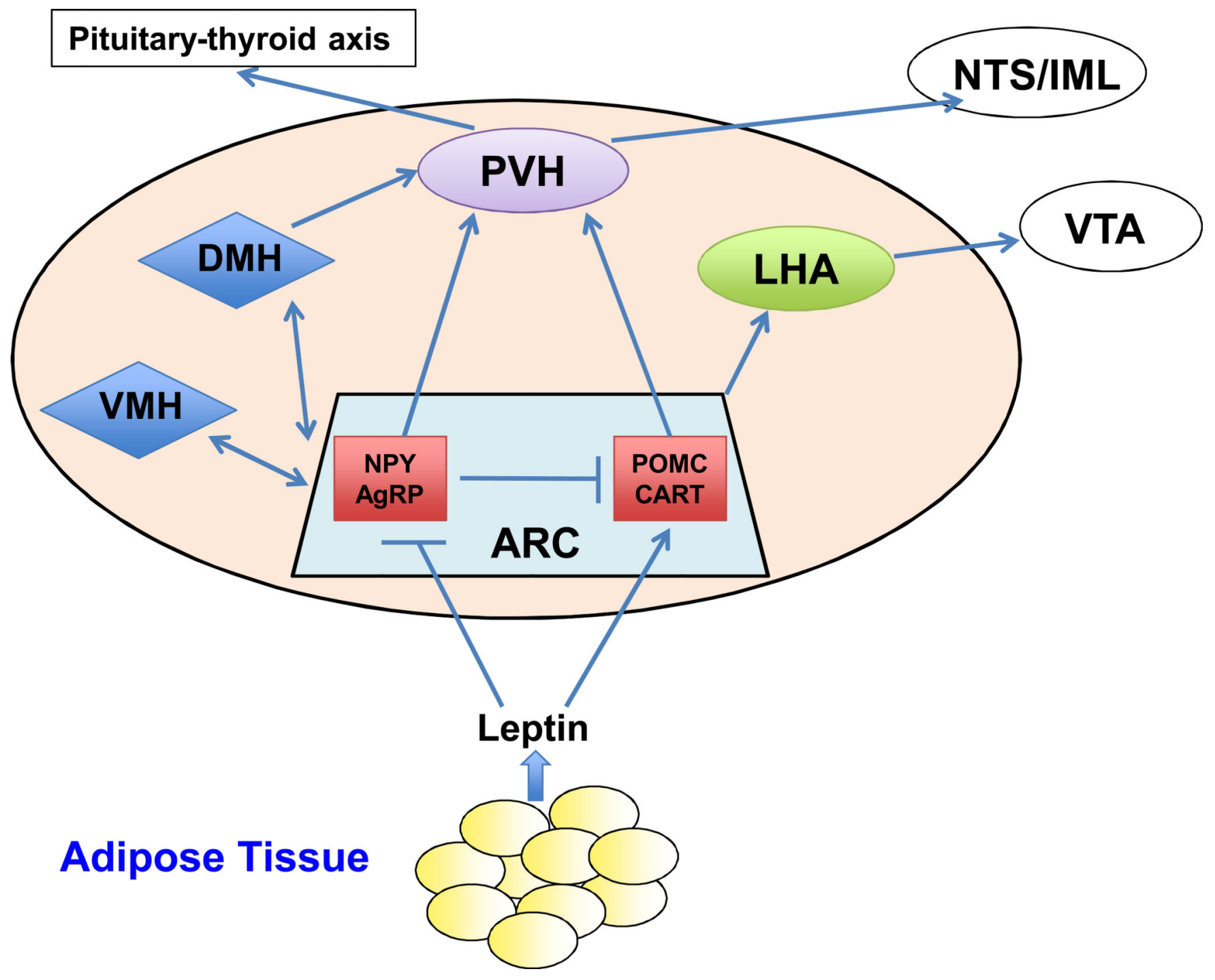

Fig. 2. Leptin-targetedt neurons and neural circuits

Leptin directly suppresses NPY/AgRP neurons and stimulates POMC/CART neurons in the ARC. ARC neurons project to multiple hypothalamic areas including the $\mathrm{DMH}, \mathrm{VMH}$, PVH, and LHA. Leptin also directly activates LEPRb in DMH, VMH, PVH, and LHA neurons. The PVH and LHA are important hypothalamic output pathways that mediate leptin's anti-obesity action. VTA: ventral tegmental area; NTS: solitary nucleus; IML: intermediolateral cell column. 